\title{
PHYTOCOENOTIC PORTRAIT OF THE EUROPEAN BADGER
}

\author{
O. I. Evstigneev ${ }^{1}$, O. V. Solonina, ${ }^{1,2}$ \\ 1 State Nature Reserve "Bryanskii Les", Nerussa Station, Bryansk Oblast, 242180, Russia \\ E-mail: quercus_eo@mail.ru \\ ${ }^{2}$ Center for Forest Ecology and Productivity of the Russian Academy of Sciences, \\ 84/32 Profsojuznaya street, Moscow, 117485, Russia \\ E-mail: caniformia@mail.ru
}

Abstract. The European badger takes part in creating intracenotic and intercenotic flows of plant diaspores. This is evidenced by the fact that its diet includes plant species belonging to different communities, i.e. forest, meadow, marsh and water communities. Badgers move plant diaspores in three different ways: endozoochory, epizoochory, and synzoochory. Therefore seeds of the maximum number of plant species with various adaptations for zoochory are involved in diaspore flows. It has been proved that badgers can move large amount of diaspores over a distance of one kilometer, and in smaller amounts - up to two or three kilometers. Because of the badgers' foraging and construction activities, the species diversity of vascular plants in their settlements has increased by one and half times. Thanks to badgers, the plant species composition of the community becomes mixed. Plant species of the meadow, black alder, boreal and piny ecological-coenotic groups co-dominate in the ground cover of nemoral forests. Badgers searching for food disturb the soil cover and create a mosaic of the ground vegetation cover throughout the family's habitat which amounts to several hundred hectares. This heterogeneity includes three types of microcommunities: 1) with a predominance of vegetatively immobile annual and biennial plants of the ruderal group (Alliaria petiolata, Geranium robertianum, Lactuca serriola, Moehringia trinervia, Polygonum convolvulus, etc.); 2) with a predominance of vegetatively mobile perennials of the ruderal group (Galium odoratum, Glechoma hederacea and Stellaria holostea), and with a significant participation of phytocenotically tolerant plants (Asarum europaeum, Polygonatum multiflorum, Pulmonaria obscura, Viola mirabilis, etc.); 3) with a predominance of the vegetatively mobile perennials of the competition group (Aegopodium podagraria, Carex pilosa, and Convallaria majalis). This sequence of microcommunities is a microsucession. Competitive species are the driving force of group development as they gradually crowd out ruderal and tolerant plant species. Competitive species can become a dominant in the ground vegetation cover for a long time. However, the badgers' use of the community territory according to the "shift" system occasionally interrupts these unidirectional microsuccesions. The disturbances created by badgers and cyclical microsuccesions maintain the multispecies composition in the herbaceous cover of forest communities. These facts indicate that earlier the badger was an edificator (key species) in the ground vegetation of undisturbed biocenotic cover. Recently, however, due to overhunting and relentless poachers' attacks, the badger has become a rare endangered species. This animal is not an active environment-transforming part of the community anymore and it as good as stopped active moving of plant diaspores, which is needed for coenotic restoration.

Keywords: European badger, Meles meles, zoochory, species diversity of communities, environmental transformation, mosaic of ground vegetation cover, microcommunities, microsucession, coniferous-deciduous forest.

Acknowledgments. The authors express their gratitude to V. N. Korotkov, A. V. Gornov and E. F. Sitnikova for manuscript review and critical comments as well as to N. V. Sidorchuk for advice. Particular gratitude is expressed to Alexey Subbotin, the animal painter, for his permission to use his excellent drawing "Badgers" in our article. The research by post-graduate student O. V. Solonina was funded by the Russian Foundation for Basic Research (project no. 19-34-90032) and was also carried out within the state assignment of the Center for Forest Ecology and Productivity of the Russian Academy of Sciences "Methodological approaches to assessing the structural organization and functioning of forest ecosystems" (the state registration number AAAA-A18-118052400130-7).

For citation: Evstigneev O.I., Solonina O.V. Phytocenotic portrait of the european badger. Russian Journal of Ecosystem Ecology. 2020;5(1). Available from: https://doi.org/10.21685/2500-0578-2020-1-3

\section{ФИТОЦЕНОТИЧЕСКИЙ ПОРТРЕТ БАРСУКА ЕВРОПЕЙСКОГО}

\section{О. И. Евстигнеев ${ }^{1}$ О. В. Солонина, ${ }^{1,2}$}

${ }^{1}$ Государственный природный биосферный заповедник «Брянский лес»,

Россия, 242180, Брянская область, станция Нерусса

E-mail: quercus_eo@mail.ru

2 Центр по проблемам экологии и продуктивности лесов РАН,

117485, Россия, г. Москва, ул. Профсоюзная, 84/32

E-mail: caniformia@mail.ru 
Аннотация. Барсук участвует в создании внутриценотических и межценотических потоков диаспор растений. Об этом свидетельствует присутствие в его рационе видов, принадлежащих к разным сообществам: лесным, луговым, болотным и водным. Барсук перемещает диаспоры растений тремя способами: эндозоохорным, эпизоохорным и синзоохорным. Благодаря этому в потоки диаспор вовлекаются семена максимального числа видов растений с разнообразными приспособлениями к зоохории. Показано, что барсук может перемещать диаспоры в массовом количестве на расстояние до одного километра, а в умеренном - до двух-трех. Трофическая и строительная деятельность барсука увеличивает видовое разнообразие сосудистых растений на поселениях в полтора раза. Благодаря этому животному флора в сообществе становится смешанной. В травяном покрове неморальных лесов начинают содоминировать луговые, черноольховые, бореальные и боровые виды. Занимаясь поисками пищи, барсук нарушает почвенный слой и создает мозаику травяного покрова на всем пространстве обитания семьи, которое составляет несколько сотен гектар. Эта гетерогенность состоит их трех вариантов микрогруппировок: 1) с преобладанием вегетативно неподвижных однолетников и малолетников реактивной группы (Alliaria petiolata, Geranium robertianum, Lactuca serriola, Moehringia trinervia, Polygonum convolvulus и др.); 2) с доминированием вегетативно подвижных многолетников реактивной группы (Galium odoratum, Glechoma hederacea и Stellaria holostea), а также со значительным участием фитоценотически толерантных растений (Asarum europaeum, Polygonatum multiflorum, Pulmonaria obscura, Viola mirabilis и др.); 3) с господством вегетативно подвижных многолетников конкурентной группы (Aegopodium podagraria, Carex pilosa и Convallaria majalis). Эта последовательность микрогруппировок представляет собой микросукцессию. Движущей силой развития группировок выступают конкурентные виды. Они постепенно вытесняют реактивные и толерантные растения. Конкурентные виды могут надолго стать доминантами травяного покрова. Однако использование барсуками территории сообщества по «переложной» системе периодически прерывает эти однонаправленные микросукцессии. Благодаря нарушениям, которые создают барсуки, и циклическим микросукцессиям поддерживается многовидовой состав в травяном покрове лесных сообществ. Приведенные факты свидетельствуют о том, что барсук в ненарушенном биоценотическом покрове был эдификатором (ключевым видом) в ярусе трав. Однако в последнее время из-за перепромысла и упорного преследования браконьерами барсук превратился в редкое исчезающее животное. Этот зверь перестал быть активным средопреобразователем в сообществе и практически полностью прекратил перемещать диаспоры растений, которые необходимы для восстановления ценозов.

Ключевые слова: барсук европейский, Meles meles, зоохория, видовое разнообразие сообществ, средопреобразование, мозаичность травяного покрова, микрогруппировка, микросукцессия, хвойно-широколиственный лес.

\section{Introduction}

Understanding the mechanisms of biological diversity maintenance in nature is the basis for developing methods of rational nature management. Climax (undisturbed) biogeocoenoses of preagricultural times differing in their maximum species diversity are highly suited for revealing these mechanisms. However, centuries of human activity have eliminated undisturbed coenoses within the territory of Europe [1, 2]. This makes the reconstruction of the climax structure of individual communities and the entire biogeocenotic cover an important ecological task. Revealing the mechanisms of biological diversity maintenance associated with the vital activity of populations of the remaining edificators $[3,4]$ is one of the possible ways of such reconstruction. One of the edificators in the forest zone of Central Russia is the European badger (Meles meles Linnaeus, 1758), which has recently become extremely rare due to overhunting and poaching [5].
The purpose of this paper is to analyse the role of the badger in the formation and maintenance of structural and species diversity of the vegetation cover.

\section{Study objects, area and methods}

Object of research. The article focuses on the European badger (Fig. 1) and its effect on vegetation. The research was carried out in the Bryanskii Les reserve and the surrounding area. There are 13 known used and abandoned settlements ${ }^{1}$ of this animal [6]. The badger is on the list of endangered species of Bryansk oblast [5]. Although it is a forest predator, it can also be found in non-forest areas. It is omnivorous and feeds on both animals and plants [7].

${ }^{1}$ Following in the footsteps of Yu. S. Lobachev [8], we understand settlement as a sett or a group of setts that are occupied by a lone badger or a badger family. Synonyms of this concept are "town" [9], "badger sett" [10], "colony" [11] or "den" [12]. Large settlements are sometimes called "fortresses" [13]. 


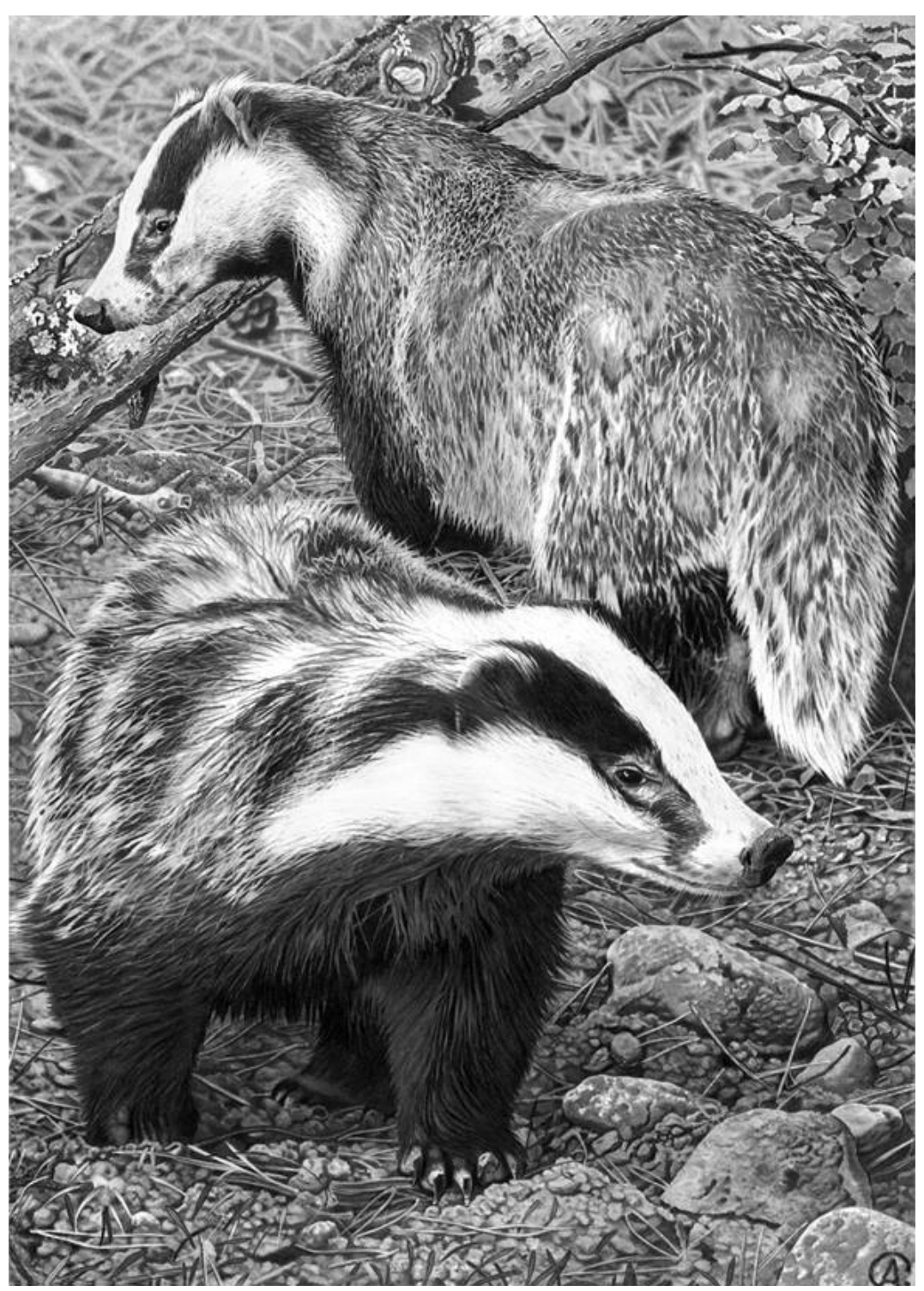

Fig. 1. Object of study, the European Badger (Meles meles Linnaeus, 1758). Image by Aleksey Subbotin [14]. The drawing was made with a lead pencil

Study area. The research was mainly carried out in the south-east of Bryansk oblast in the Nerusso-Desnyanskoye Polesie. According to the phytogeographical division, this physiographical region is a northern broad-leaved forest with a small participation of spruce trees, belonging to the Polesie sub-province of the Eastern European province of the European broad-leaved forest region [15]. Additionally, edificatory properties of the badger were studied on the territory of the Markovskiye Gory and Pechnoye natural monuments. The first monument is located within the Pogarskoye high plains and the second one in the Komarichsko-Sevsky physiographical region. A phytogeographical description of these monuments has been provided earlier [16]. All research sites are part of the Central Russian region of the province of mixed forests of the boreal-forest subdistrict of the Palearctic region [17] in terms of zoogeography.
Methods of research. Two groups of geobotanical descriptions were made at badger settlements. In the first group, rectangular plots of $100 \mathrm{~m}^{2}$ each were established at each settlement. At the same time, a control plot was established outside the settlement, where the impact of the badger was minimal. In both cases, three layers of the forest were characterised, i.e. the forest stand, undergrowth and underbrush, as well as herbaceous cover. Nine descriptions were made for settlements and control sites. Establishment of the plots for the second group of descriptions was preceded by a preliminary typing of the mosaic pattern of the herbaceous cover surrounding the settlements, according to the degree of disturbance by badgers. Three mosaic pattern types were identified. The first type included sites with 90 to $100 \%$ disturbance of the herbaceous cover, the second had sites with 40 to $90 \%$ disturbance, and the third site had 1 to $40 \%$. We generated a disturbance gradation-based map 
of the herbaceous cover around badger settlements via GPS and MapInfo. Each type of the herbaceous cover mosaic involved establishing rectangular areas of $1 \mathrm{~m}^{2}$. In total, 56 descriptions were completed: 14 in the first site type and 21 both in the second and third types. The Braun-Blanquet scale was used to evaluate the participation of species in all groups of geobotanical descriptions [18]. The occurrence of species in the community was expressed in points with equal classes: class I corresponds to occurrence from 1 to $20 \%$, class II to occurrence from 21 to $40 \%$, class III to 41 to $60 \%$, class IV to 61 to $80 \%$, and class V to 81 to $100 \%$. Species names are given according to Mayevsky [19].

Geobotanical descriptions were used to assess the diversity of communities, i.e. species richness of vascular plants, species density, distribution of species by ecological-coenotic groups and types of plant strategies. Species richness is the number of species in a single community type and defined as the total number of species on all sites belonging to one type of coenosis. Species density is the arithmetic mean of species on fixed-size plots obtained from all descriptions of a single community type [20]. Following in the footsteps of Nitsenko [21], we understand ecological-coenotic groups (ECGs) as large groups of ecologically related species, which in their genesis are associated with different types of communities. We used the classification of species by ECGs, which was developed for the European part of Russia [22] and is available on the website of the Institute of Mathematical Problems of Biology of the Russian Academy of Sciences (http://www.impb.ru/index.php?id=div/lce/ ecg). We understand the type of plant strategies as the potential ability of a species to dominate or occupy a subordinate position in the community which had developed as a result of long-term evolution in pre-agricultural climax cenoses [23]. To assign species to a particular type of plant strategies, we used the classification developed by Smirnova [24]. In this paper, the ratio of the number of species by ECGs and plant strategies types was determined based on the list of all species found in one variant of the community.

\section{Results and discussion}

Omnivory is a feature of badgers and significant for vegetation cover in two aspects. First, eating plant diaspores ${ }^{2}$, badgers spread the parts that

\footnotetext{
${ }^{2}$ Diaspore (disseminule) is a part of the plant that provides propagation, reproduction and dispersal of the species $[25,26]$. Diaspores can be represented by seeds, fruits, infructescences, vegetative disseminules and other parts of the plant $[27,28]$.
}

are necessary for the successional development of communities. Second, foraging for small animals and underground parts of plants, the badger digs the upper soil layer and creates a mosaic structure of the herbaceous cover, which has to be formed constantly to maintain species diversity of cenoses.

\section{Badgers and the composition of plant feed}

Data on the species composition of plants that the badger feeds on are important for studying successions in the vegetation cover. This is because, together with the plants, the badger swallows their diaspores and transfers them to a certain distance. At the same time, finding out the composition of plant food allows us to identify badger habitats with the optimal combination of communities.

Literature analysis has shown that the badger's diet contains more than 70 species of vascular plants of natural flora (Table 1). The majority $60 \%-$ belongs to forest species. It is for a reason that zoologist Jurgenson emphasises the forest features of a badger: smell, hearing and touch are its best developed senses; like many forest predators, it is short-sighted but sees perfectly at a short distance [29]. Detailed analysis of the feed has revealed that forest plants included both nemoral and boreal species. Examples of nemoral plants are Cerasus avium, Convallaria majalis, Cornus sanguinea, Euonymus europaea, Malus sylvestris, Viburnum opulus, Padus avium, Pyrus communis, Sambucus nigra, among others. Examples of boreal plants are Frangula alnus, Rubus idaeus, R. nessensis, $R$. saxatilis, Sorbus aucuparia, Vaccinium myrtillus, $V$. vitis-idaea, among others. This indicates that a badger originally inhabits mixed coniferous-broad-leaved forests. According to modern geobotanical concepts, pure coniferous and broadleaved forests have evolved from mixed coniferous-broad-leaved communities as a result of human activity $[1,30]$. It should be emphasised that there is a significant proportion of meadow species in the feed, i.e. $26 \%$. There are also black alder, sphagnum and water-accompanying plants, with a total participation of $14 \%$ (see Table 1). This means that important badger habitats, apart form coniferous-broad-leaved forests, include dry and wet meadows and clearings, lowland and upland swamps, as well as water communities. No wonder zoologists outline that the optimal badger biotope is a mosaic vegetation cover where forests of different types alternate with meadows, clearings, forest edges, swamps and floodplains of streams [7, 31]. Meadows and clearings in forests are currently created and maintained by humans, whereas in pre-agricultural times, they were formed under the influence of foraging and migration of large gregarious ungulates that largely inhabited coniferous-broad-leaved forests [1]. 
Plant species composition in the European Badger's diet in the forests of Eastern Europe

\begin{tabular}{|c|c|c|}
\hline \multicolumn{2}{|c|}{$\begin{array}{l}\text { Ecologico-cenotic } \\
\text { groups }\end{array}$} & Plant species or genus \\
\hline \multirow[t]{2}{*}{ 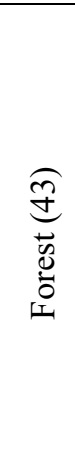 } & 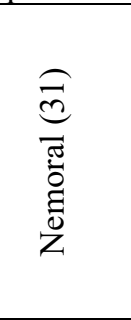 & $\begin{array}{l}\text { Acer platanoides L., Acer pseudoplatanus L., Allium ursinum L., Betula pendula Roth, Carex } \\
\text { pilosa Scop., Carpinus betulus L., Cerasus avium (L.) Moench, Convallaria majalis L., Cornus } \\
\text { sanguinea L., Corydalis solida (L.) Clairv., Corylus avellana L., Dentaria quinquefolia Bieb., } \\
\text { Euonymus europaea L., E. verrucosa L., Fagus sylvatica L., Festuca sp., Fraxinus excelsior L., } \\
\text { Gagea lutea (L.) Ker-Grawl., Galathus nivalis L., Lilium martagon L., Luzula sylvatica (Huds.) } \\
\text { Gaudin, Malus sylvestris L., Mercurialis perennis L., Padus avium Mill., Populus tremula L., } \\
\text { Pyrus communis L., Quercus robur L., Sambucus nigra L., Taxus baccata L., Tilia sp., and } \\
\text { Viburnum opulus L. }\end{array}$ \\
\hline & 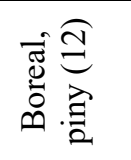 & $\begin{array}{l}\text { Cornus alba L., Frangula alnus Mill., Juniperus communis L., Picea abies (L.) Karst., Pinus } \\
\text { sibirica Du Tour, P. sylvestris L., Rubus idaeus L., R. nessensis W. Hall, R. saxatilis L., Sorbus } \\
\text { aucuparia L., Vaccinium myrtillus L., and V. vitis-idaea L. }\end{array}$ \\
\hline \multicolumn{2}{|c|}{$\begin{array}{l}\text { Black alder, } \\
\text { sphagnum, water } \\
(10)\end{array}$} & $\begin{array}{l}\text { Alnus glutinosa (L.) Gaertn, Lemna minor L. s.l., L. trisulca L., Oxycoccus palustris Pers., } \\
\text { Phragmites australis (Cav.) Trin. ex Steud., Potamagrton sp., Ribes sp., Salix sp., Typha sp., } \\
\text { and Urtica dioica L. }\end{array}$ \\
\hline \multicolumn{2}{|c|}{$\begin{array}{l}\text { Meadow, forest- } \\
\text { edge (19) }\end{array}$} & $\begin{array}{l}\text { Allim sp., Capsella bursa-pastoris (L.) Medik., Cerasus fruticosa Pall., Cirsium sp., Crataegus } \\
\text { sp., Crocus heuffelianum Herb., Equisetum sp., Fragaria vesca L., F. viridis (Duch.) Weston, } \\
\text { Hedysarum sp., Lamium album L., Potentilla anserina L., Prunus spinosa L., Ranunculus sp., } \\
\text { Rhamnus cathartica L., Rubus caesius L., Rosa canina L., Trifolium sp., and Tulipa } \text { sp. }\end{array}$ \\
\hline \multicolumn{2}{|c|}{$\begin{array}{c}\text { Cultural, } \\
\text { adventitious (28) }\end{array}$} & $\begin{array}{l}\text { Amelanchier sp., Armeniaca vulgaris Willd., Avena sativa L. s. l., Beta vulgaris L., Castanea } \\
\text { sativa Mill., Cerasus vulgaris Mill., Citrullus lanatus (Thunb.) Matsum. et Nakai, Cucumis } \\
\text { sativus L., C. melo L., Cucurbita pepo L., Daucus sativus (Hoffm.) Roehl., Fagopyrum } \\
\text { esculentum Moench, Helianthus annuus L., Hordeum sp., Juglas regia L., Malus domestica } \\
\text { Borkh., Medicago sativa L., Onobrychis viciifolia Scop., Panicum miliaceum L., Prunus } \\
\text { cerasifera Ehrh., P. domestica L., Secale cereal L., Solanum lycopersicum L., S. tuberosum L., } \\
\text { Spirea sp., Triticum sp., Vitis vinifera L., and Zea mays L. }\end{array}$ \\
\hline \multicolumn{3}{|c|}{ Source of information: $[7,8,32-52]$} \\
\hline
\end{tabular}

Note. The number of plant species is shown in parentheses

Plant feed composition analysis shows that the badger is involved in creating both intracoenotic and intercoenotic flows of diaspores. This is evidenced by its diet, which includes plants of communities of different types, i.e. forest, meadow, swamp and water (see Table 1). Intracoenotic flows of diaspores mean their migration within a single community, e.g. within the coniferousdeciduous forest. These flows are needed to preserve plant populations within the community, maintain species diversity of the coenosis and to provide intracoenotic seed successions. Intercoenotic flows of the diaspores mean the migration of disseminules between communities. These flows are necessary for changing coenoses belonging to different types. Examples of such changes are: 1) overgrowing of meadows with forest; 2) replacement of a pine forest with a coniferous-broadleaved forest; 3) conversion of shadow deciduous forests with nemoral composition of the herbaceous cover under the influence of mowing, grazing and activities of large wild animals (including badgers) in a bright parkland with a large participation of meadow species and other ecologicalcoenotic groups of plants.

\section{Badgers and zoochory}

Understanding the development of forest communities involves information about the nature of the movement of plant diaspores by different animal species. Literature analysis has shown that badgers involve plant seeds in diaspore flows in different ways: through endozoochory, epizoochory and synzoochory.

Endozoochory means the dispersal of diaspores that had passed through the digestive tract of animals and were then ejected with regurgitates or droppings [27, 28, 53]. Succulent fruits of Cerasus avium, C. fruticosa, Fragaria vesca, F. viridis, Malus sylvestris, Prunus spinosa, Pyrus communis, Rubus caesius, R. idaeus, R. saxatilis, Vaccinium myrtillus and other species serve as fattening feed for badgers [34, 45]. The pattern of endozoochorous movement of seeds depends on the season. For example, in early summer, there are numerous cherry seeds [34, 37], while in the middle summer, seeds of raspberries, stone brambles, bilberries and strawberries are abundant [42, 47, 54]. In late summer, seeds of European blackberries, apples 
and pears are numerous $[34,44]$, while in autumn, cowberry and cranberry seeds are often found in the badgers' latrine pits $[44,50]$. The actual participation of badgers in the distribution of plant diaspores can be evaluated by the following figures. In one pile of badger faeces, zoologists found 2.3 thousand bilberry seeds [51], while in another one, they counted 5.0 thousand strawberry nuts [55]. When feeding on green plant parts, at the same time, badgers eat a lot of dry fruits and seeds. Plant diaspores can participate in community formation only if they remain alive after passing through the animal's digestive tract. Obraztsov [56] showed that the viability of pear seeds that passed through the badger's digestive system was $60 \%$, while that of apple seeds was $83 \%$ and that of blackthorn seeds $100 \%$. These numbers are comparable to the viability of seeds that have passed through the digestive tract of other predators such as bears, wolves or foxes. Besides, zoologists note that badgers often leave droppings in holes specifically dug or in pits made earlier when foraging for invertebrates. These latrine pits are usually buried by the animals after they are filled [8, 49]. This defecation behaviour undoubtedly contributes to better seed germination since the soil is fertilised and the diaspores are protected from drying out.

Epizoochory means the dispersal of diaspores that cling or stick to an animal's body [27, 28, 53]. In this case, animals only passively transfer the seeds on their bodies, not benefiting from it. Plants with specific adaptations of diaspores to epizoochory, found at the settlements, include, for example, Arctium lappa [44], Geum urbanum, Leonurus quinquelobatus, Cirsium sp. (see Table 1), Carduus sp., Galeopsis ladanum and G. tetrahit [57]. Wood avens use modified clingy stilodia of nuts, whereas motherwort and hemp nettle species use the awlshaped teeth of the flower cup; burdock, thistle and bristlethistle use a prickly and clingy web-like involucre. Part of the seeds, especially small ones, is transferred with the damp soil stuck to fur and paws. An important feature in the badger's behaviour in terms of epizoochory is the cleaning of fur and the removal of adhered seeds and dirt. The animal grooms its fur every day, usually on a site at the sett. Observations have shown that one grooming session can last up to 40 minutes. Sometimes, another badger joins in, helping to groom the areas which are difficult to reach [50].

Synzoochory means the dispersal of diaspores associated with their transfer by animals for further storing them away in "larders" or eating in nests or on feeding sites [27, 28, 53]. Badgers do not store food in the classical sense. However, they harvest grass to line the nest chamber and make grass plugs to block the sett during hibernation. When collecting grass, the badger rolls it in balls $20-35 \mathrm{~cm}$ in diameter, which are then moved to the sett and left to dry in the sun for several days near the entrance [49, 58]. Some seeds and other diaspores fall out of the dry bundle and, falling on the soil thrown out of the setts, sprout. Zoologists found Pteridium aquilinum, Mercurialis perennis, Scilla sp. in the bundle, as well as species of the Poaceae family [57]. The same authors suggest that this could be the way Carduus sp., Rumex sp., Lamium purpureum, Galeopsis ladanum, and Melandrium dioicum appeared in the settlements. In this case, plants do not have to be particularly adapted for zoochory. Badgers often collect material for a bundle at a distance of 10-30 $\mathrm{m}$ from the den, sometimes in a radius of $50 \mathrm{~m}$. There was a case when animals made bundles at a distance of $230 \mathrm{~m}$ from the sett and even picked the straw that was lying in a field, $300 \mathrm{~m}$ away from the settlement, to use it for bedding $[47,49]$. The nest bedding can weigh up to $5 \mathrm{~kg}[7,9,58]$.

By moving seeds around in different ways, the badger can involve the maximum number of plant species with all possible adaptations for zoochory and even without them (for example, by making bundles of grass with seeds) into the flows of diaspores. This is evidence of the fact that the badger is an active participant in successions in the vegetation cover.

\section{Badgers and the distance of plant diaspore distribution}

The study of successions and forecasts regarding forest community development requires information about the distance that different agents, including badgers, move plant diaspores to $[1,59,60]$. The range of movement of plant diaspores can be estimated through the size (radius) of animal habitats [61, 62]. Within a family area of a badger habitat, zoologists distinguish two areas [11,33, 63].

The first one is the area with the largest number of traces of the animal's vital activity. This zone seems to be similar in size to the daily home range of one animal [64]. It is quite possible that within this zone, badgers move the largest number of plant diaspores because the majority of food, including the seeds, passes through the digestive tract of predators, including badgers, in the first day $[56,65,66]$. It can be assumed that the distance of mass dispersal of plant diaspores by this animal will correspond to the radius of the daily home range, which is $1.0-1.5 \mathrm{~km}$ (Table 2). 
Radius of the European badger family area

\begin{tabular}{|c|c|c|}
\hline $\begin{array}{c}\text { Radius of the family area where the } \\
\text { greatest number of traces of badger's } \\
\text { vital activity was found, } m\end{array}$ & $\begin{array}{c}\text { Range of the radius of the family area where a } \\
\text { relatively small number of traces of badger's } \\
\text { vital activity was found, } m\end{array}$ & Source of information \\
\hline $500-1,500$ & $1,500-3,000$ & {$[37]$} \\
\hline $900-1,100$ & $1,100-3,000$ & {$[49]$} \\
\hline $750-960$ & $960-2,300$ & {$[64]$} \\
\hline $520-710$ & $710-1,020$ & {$[67]$} \\
\hline $500-700$ & $700-2,000$ & {$[63]$} \\
\hline $300-700$ & $700-1,500$ & {$[33]$} \\
\hline $250-500$ & $500-3,000$ & {$[3]$} \\
\hline
\end{tabular}

The second area is the entire family plot, which is used by the animals from the moment they leave the sett after hibernation until the next hibernation. It can be expected that within the family area, only a moderate number of plant diaspores is moved, mainly because a relatively small part of seeds can happen to be outside the daily plot if the seeds stay in an animal's digestive tract for several days. Food, including plant disseminules, especially small ones, can remain in a badger's digestive system for up to 5 days [65]. In this case, the distance of diaspore movement gets close to the radius of the entire badger family plot, which is $2-3 \mathrm{~km}$ (see Table 2). Direct observations confirm these assumptions: badger excrements containing oats were found in a settlement that was located $3.5 \mathrm{~km}$ from the nearest oat field [47]; the remains of myrobalan plum (Prunus cerasifera), which the animal had gathered in a garden located at a distance of over 1 kilometre, were found in a sett [39].

The distance of plant diaspore movement by badgers is comparable to that of large mammals such as bear, roe deer, elk and bison [61]. While animals with relatively small areas of habitat (for example, common squirrel, yellow-necked mouse or jay) create mainly intracoenotic flows of diaspores, mammals with large plots, including badgers, create mainly intercoenotic flows of diaspores, which are necessary for the formation of the mixed flora of communities and for successional transformations of coenoses $[62,69]$.

\section{Badgers and species diversity of communities}

When looking at the locations of badger setts in the Bryanskii Les reserve and its surroundings, we revealed that settlements are currently located in communities with the predominance of nemoral species $^{3}$. These cenoses are represented by broadleaved and coniferous-broad-leaved forests as well as aspen forests. Quercus robur, Fraxinus excelsi-

${ }^{3}$ It is believed that the nemoral floristic complex unites the species whose range and history are related to European broad-leaved forests [70]. or, Acer platanoides, Tilia cordata and Populus tremula form the main tree stand in badger habitats. Apart from the tree layer species, the undergrowth also includes Ulmus glabra, Malus sylvestris and Cornus sanguinea, Corylus avellana, Euonymus europaea and E. verrucosa shrubs. The herbaceous cover is dominated by Aegopodium podagraria, Carex pilosa, Convallaria majalis, Mercurialis perennis, Glechoma hederacea, Lamium maculatum and Stellaria holostea. There is also an admixture of Asarum europaeum, Galeobdolon luteum, Lathyrus niger, Pulmonaria obscura, Viola mirabilis, among others. Nemoral forests are usually found in sandy areas that include loamy material. Within these areas, badgers choose wooded ridges with slopes suitable for digging setts. Zoologists have proven that in inhabited setts, the sleeping chamber (den, nest), for sleeping and cub delivery, is mainly built in the sand under loam arches. Loam reinforces the sett and forms a waterproof ceiling above the living chamber, whereas sand, which is easy to dig in, has poor thermal conductivity and provides favourable temperature and good drainage if water enters the sett [9].

It is well known that the badger prefers lived-in setts. Formozov [71] emphasises that "this animal always sticks to the places it once chose". Likhachev [9] explains that such site fidelity is caused by the rarity of the places where permanently inhabited setts can be dug. If a badger has found suitable housing conditions, it leaves its home only after persistent persecution by poachers and always seeks to return to its old shelter. Permanent setts that are used for hibernation and for cub delivery and rearing have been existing for hundreds or even thousands of years [72]. As a result, badger setts gradually turn into large sett complexes and then into even larger settlements with a significant area reach. For example, in the Oka reserve, a sett occupying 2,500 $\mathrm{m}^{2}$ was found [73], while in Bryansk oblast, a sett of $3,800 \mathrm{~m}^{2}$ was found [74]. In England, a settlement of $17,500 \mathrm{~m}^{2}$ was found [75]. The researchers found 31 entrance holes in the first case, 17 in the second and 178 in the third. 
With such a long-term use of the territory, the vegetation cover of settlements (accumulative effect) gradually changes: the structure of the stand, undergrowth and underbrush is changing, and the species composition of the herbaceous cover is transformed. On old badger settlements, the closure of the forest stand is reduced to $20 \%$ or less. This is because adult trees gradually fall and are not replaced by young ones. Singular undergrowth plants preserved in the settlements show low vitality since the bark is stripped off the stems or damaged by badgers, which eat the sweet sap and the nutritious phloem [57]. For this reason, the bark of woody plants is frequently found in badger excrements $[44,52]$. The trunks of shrubs and undergrowth of trees often have numerous deep scratches left by the badger sharpening its claws (Fig. 2). At the same time, this animal prevents trees and shrubs from taking root by eating their fallen fruits and sprouted seedlings [33, 34, 52, 58]. Therefore, no sprouts of common hazel, wartybark euonymus or witch elm were found in badger settlements, although there were fruit-bearing plants of these species nearby; the number of seedlings of Norway maple and common ash was a quarter lower than it was outside the settlement.

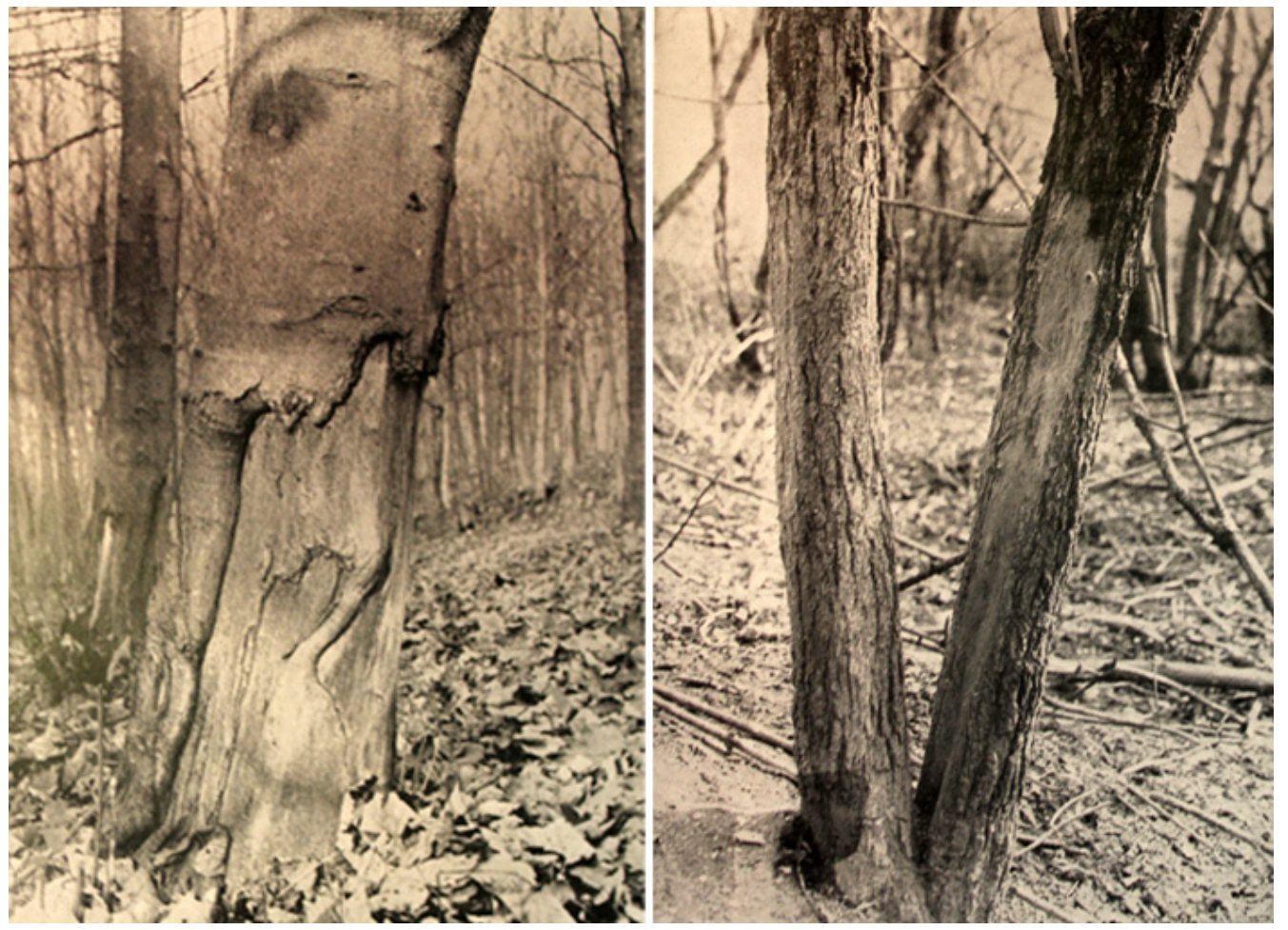

Fig. 2. Traces of life activity of the European badger on the stems of woody plants. On the left is the bark of the sycamore maple (Acer pseudoplatanus) peeled in early spring for the extraction of sweet juice. On the right is the peeled bark of elderberry (Sambucus sp.) with many deep scratches from the badger's claws [52, 76]

This impact has resulted in the gradual thinning of the tree stand, the disappearing of the undergrowth and the increase of herbaceous cover illumination in comparison with the surrounding forest. This contributes to the introduction of lightdemanding plants into previously dark nemoral forests. Their diaspores are constantly brought in by badgers, and badger activity significantly increases species density and species richness of vascular plants in the settlements as compared to the settlement surroundings (Table 3). Diversity indicators increase mainly due to meadow species brought here from open sunny places, i.e. forest edges, clearings and meadows. Meadow plants include Achillea millefolium, Anthriscus sylvestris, Carex echinata, Chelidonium majus, Chenopodium album, Clinopodium vulgare, Erigeron annuus, E. canadensis, Equisetum pretense, Fragaria ves- ca, Galium mollugo, G. physocarpum, Hypericum perforatum, Lactuca serriola, Leonurus quinquelobatus, Polygonum convolvulus, Prunella vulgaris, Rorippa sylvestris, Solidago virgaurea, Taraxacum officinale, Veronica chamaedrys, Viola canina, among others. Black-alder-associated species, which are not typical of nemoral forests, i.e. Athyrium filix-femina, Ribes nigrum, Solanum dulcamara and Urtica dioica, appear in the herbaceous cover of sett complexes. At the same time, the species composition of the nemoral group is significantly expanded in badger settlements in comparison with the control group. Actaea spicata, Ajuga reptans, Cystopteris fragilis, Festuca gigantean, Geranium robertianum, Lamium maculatum, Lathyrus niger, Moehringia trinervia, Scrophularia nodosa and Viburnum opulus can be found here. The participation of light-loving piny plants and 
some shade-tolerant boreal species is increasing in the community. Piny species include Pteridium aquilinum and Rubus idaeus, whereas boreal ones include Luzula pilosa, Maianthemum bifolium and Rubus saxatilis.

Table 3

Number of vascular plant species in the herbaceous layer in badger settlements and in the control

\begin{tabular}{|c|c|c|c|}
\hline \multirow{2}{*}{ Settlement number } & \multirow{2}{*}{ Nature of the settlement } & \multicolumn{2}{|c|}{ Number of species } \\
\hline & & Settlement & Control \\
\hline 1 & Inhabited & 42 & 31 \\
\hline 2 & Inhabited & 41 & 23 \\
\hline 3 & Inhabited & 37 & 20 \\
\hline 4 & Inhabited & 33 & 17 \\
\hline 5 & Inhabited & 33 & 14 \\
\hline 6 & Uninhabited & 25 & 15 \\
\hline 7 & Uninhabited & 25 & 15 \\
\hline 8 & Uninhabited & 21 & 20 \\
\hline 9 & Uninhabited & 21 & 16 \\
\hline \multicolumn{2}{|c|}{ Species density, $M \pm m_{M}$} & $30.9 \pm 2.73$ & $19.0 \pm 1.80$ \\
\hline \multicolumn{2}{|c|}{ Mann-Whitney test, value, $U$} & \multicolumn{2}{|c|}{$6.0(p=0.0026)$} \\
\hline
\end{tabular}

Note. $M$ is the arithmetic mean, $m_{M}$ is the arithmetic mean error, $p$ is the significance value of differences in species density; significant differences are shown in bold. Species density is the average number of species on nine plots of $100 \mathrm{~m}^{2}$. Species richness is the total number of species on all nine plots of $100 \mathrm{~m}^{2}$.

Geobotanical surveys of settlements have shown that foraging and construction activities of badgers change the ecological-coenotic composition of communities; the flora becomes mixed (Fig. 3). Due to badgers' activities, pure nemoral forests are being replaced by cenoses where meadow species start to co-dominate. At the same time, the role of black alder, boreal and piny plants, which are not

\section{Settlements (79 species)}

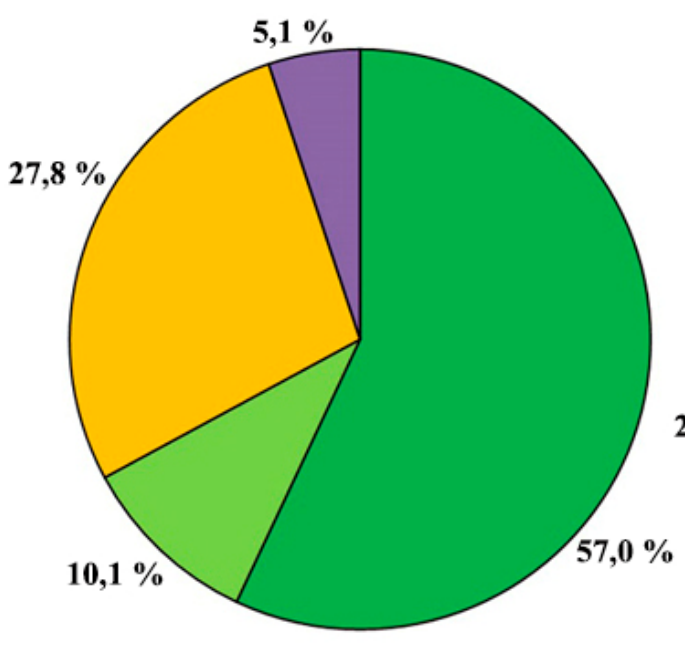

\section{Ecologigal-coenotic groups of plants:}

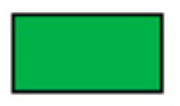

Nemoral

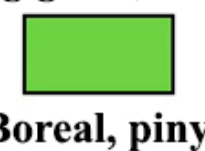

typical of modern nemoral communities, is increasing. Based on previous studies, light forests with mixed flora were the primary form and were typical of undisturbed (climax) coenoses of preagricultural times. Such communities were created and maintained by different groups of animals $[1,3,77]$.

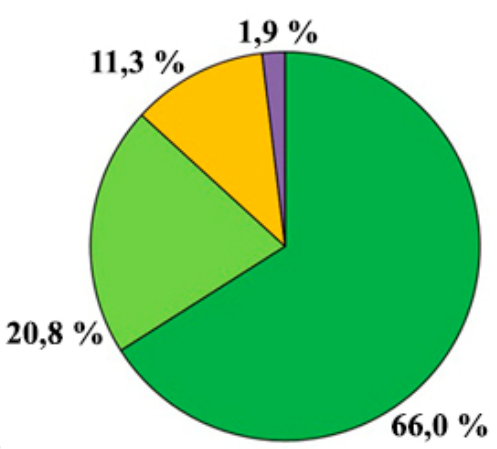

\section{Control (53 species)}

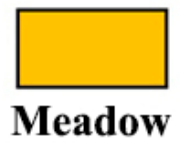

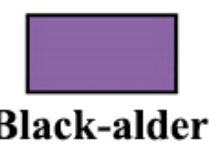

Fig. 3. The ratio of plant species of different ecological-coenotic groups in the settlements of badgers and in the control. Species richness is indicated in brackets. The area of the circle corresponds to species richness. Nine vegetation sample plots ( $100 \mathrm{~m}^{2}$ each) were established at the settlement and at the control 


\section{Badgers and soil cover disturbances}

Based on the literature, digging activity of animals comparable in size to badgers creates heterogeneity of the soil cover in the community, which is characterised by a peculiar ecological regime $[78,79,83]$. The area of individual digging sites (disturbances) of these animals is usually small, not more than several square decimetres or metres. The elements of such a mosaic are called microsites or micro-habitats $[18,80]$. Unique microgroups (microcoenoses) of plants and animals $[81,82]$, which are characterised by specific dynamic processes called microsuccessions [3, 83], are formed on microsites. Badgers create two types of soil disturbance, which differ in functional purpose.
The first type of disturbances is the result of the badger's construction activity. These violations are related to soil spoils (the so-called "butans" ${ }^{4}$ or mounds) made at the settlement during cleaning, renovation, expansion and deepening of old setts, as well as the construction of the new ones (Fig. 4). Setts can be 3-6 m deep [7, 10]. The area of individual mounds of earth is 2 to $23 \mathrm{~m}^{2}$. Thereat, animals carry 0.7 to $8.1 \mathrm{~m}^{3}$ of soil [49] to the surface. In some cases, the spoil area reaches $55.0 \mathrm{~m}^{2}$, with a volume of up to $10.0 \mathrm{~m}^{3}$ [42]. The soil thrown to the surface is enriched with minerals, and the microrelief near the sett changes: butans up to $80 \mathrm{~cm}$ high, foot-worn by badgers, are formed. These micro-habitats have a unique species composition of plants and soil invertebrates [78, 84, 85].
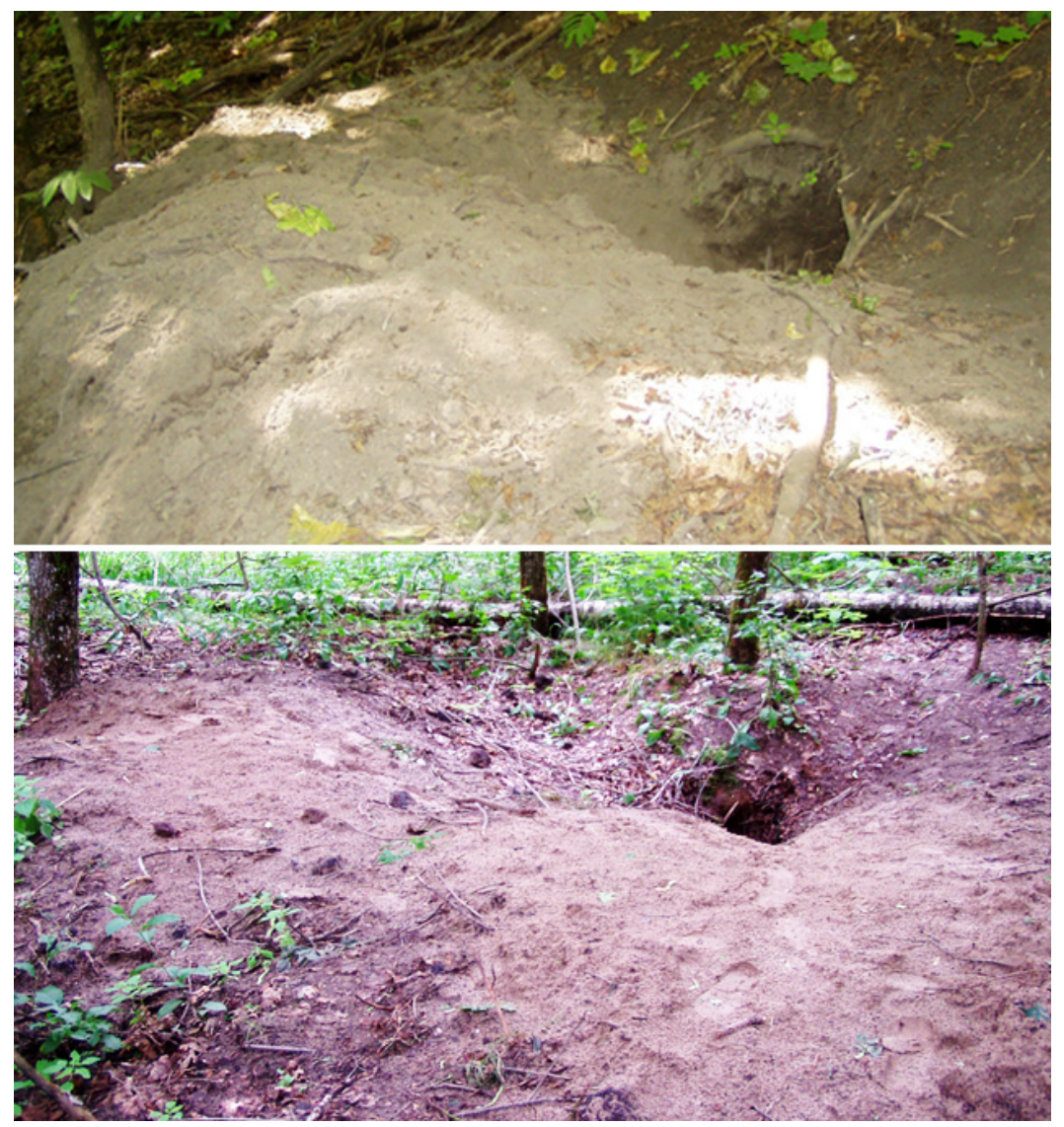

Fig. 4. Disturbance of the soil cover by the European badger associated with soil ejection during cleaning, renewal, expansion and deepening of old setts, as well as the construction of new ones. Image courtesy of E. F. Sitnikova

The second type of disturbances is a consequence of the badger's foraging activity. Looking for invertebrates and small vertebrates, as well as juicy underground plant parts, it has to dig through the upper soil layers. These disturbances are usually dispersed throughout the family area. The badger mainly shows four patterns of digging, which

\footnotetext{
4 "Butan" is an individual steppe hill; a mound, a hill on the plain, a hillock dug by marmots, steppe marmots or tarbagans [89]. This term is also used by some zoologists who study badgers $[8,49,58]$.
}

are a result of different foraging ways [47]. The first type is small digs with an area of $30 \mathrm{~cm}^{2}$ and up to $10 \mathrm{~cm}$ deep (Fig. 5, $A, B$ ). They are created by badgers looking for grubs of cockchafers and other invertebrates. For one meal, the animal makes 30 to 2,700 small digs per $100 \mathrm{~m}^{2}$ [42, 45, $86,87]$, disturbing up to $8 \%$ of the soil cover area. The second type is round-shaped violations with an area of about $500 \mathrm{~cm}^{2}$ and up to $35 \mathrm{~cm}$ deep (Fig. 5, C). These digs are made by badgers extracting diggers and bumblebees. The third type is 
oblong and round-shaped pits with an area up to $1,000 \mathrm{~cm}^{2}$ and up to $45 \mathrm{~cm}$ deep (Fig. 5, D, E). They appear during digging into dens of mice, voles, moles, shrews and other small vertebrates $[42,47]$. In Leningrad oblast, when surveying the area around the settlement, zoologists estimated that badgers dug up 209 mole channels of 284 [87]. At the same time, predators hunt not only moles; they also search for earthworms and other invertebrates that inhabit underground mazes. The fourth type of disturbances is represented by the top layer of soil that badgers dug up and turned over with muzzles and front claws over a considerable distance (Fig. 5, F). The area of such disturbances can reach $900 \mathrm{~m}^{2}$ and even a quarter of a hectare $[42,88]$. In appearance and scope of changes, they are similar to traces of boar feedings [40]. In the upper soil layer, badgers look for earthworms and other invertebrates, as well as for tubers and bulbs of spring ephemeroids - Corydalis solida, Gagea lutea, Galathus nivalis, rhizomes of summer broad-leaved grasses - Mercurialis perennis, Dentaria quinquefolia, etc., fallen fruits of trees and shrubs - Acer platanoides, Carpinus betulus, Cerasus avium, Corylus avellana, Fagus sylvatica, Fraxinus excelsior, Quercus robur, Tilia cordata, etc. $[33,34,48,52]$.
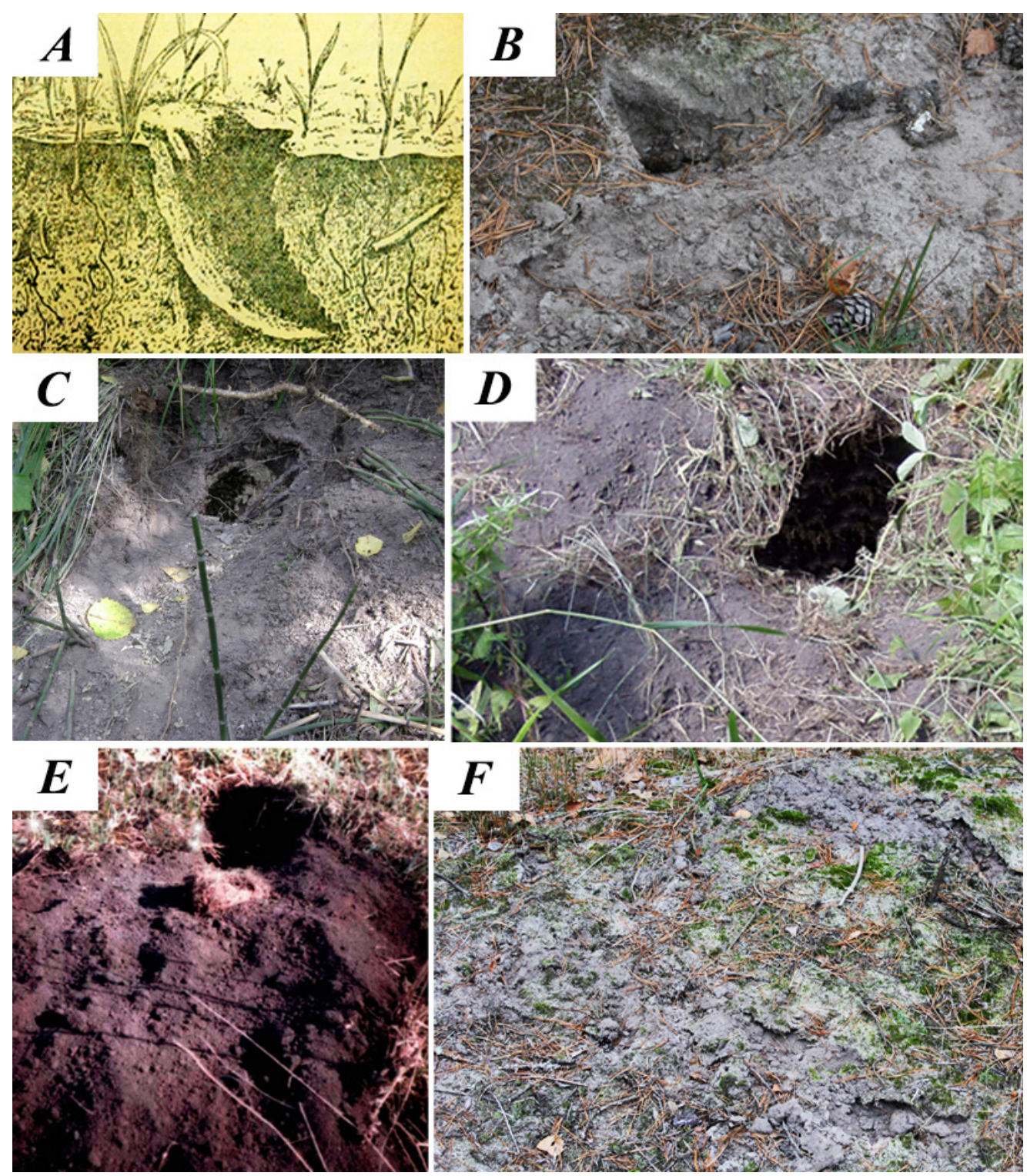

Fig. 5. Disturbance of the soil cover associated with foraging activity of the European badger: A, B - small digs (both plane and elevated) with an area of $30 \mathrm{~cm}^{2}$ and up to $10 \mathrm{~cm}$ deep, made during the extraction of larvae of cockchafers and other invertebrates; $C$ - round-shaped disturbances with an area of about $500 \mathrm{~cm}^{2}$ and up to

$35 \mathrm{~cm}$ deep, made during the extraction of diggers (remains of honeycombs are visible in the excavation);

$D, E$ - oblong and rounded pits with an area of up to $1,000 \mathrm{~cm}^{2}$ and up to $45 \mathrm{~cm}$ deep, made during excavations of the setts of small mouse-like rodents (an ejected bedding of rodents is visible near the excavation);

$F-$ an excavated and inverted topsoil in which badgers searched for invertebrates, rhizomes, tubers and bulbs of plants. Image courtesy of: A - [55]; B, F - O. V. Solonina; C - [90]; D - E. F. Sitnikova; E - [47] 
Most of the figures characterising badger's digging activities will increase by manifold if calculated for the entire season and for the entire family living in the settlement. All this is proof that the badger is originally an edificator of the herbaceous cover. Due to vigorous construction and foraging activity, it can actively create a mosaic pattern in the herbaceous layer throughout the family's habitat. Zoologists have shown that a badger family area can reach several hundred hectares $[64,67]$.

\section{Badgers and mosaic pattern of the herbaceous cover}

Three zones are distinguished in the herbaceous cover in terms of the intensity of the disturbances produced by badgers (Fig. 6).

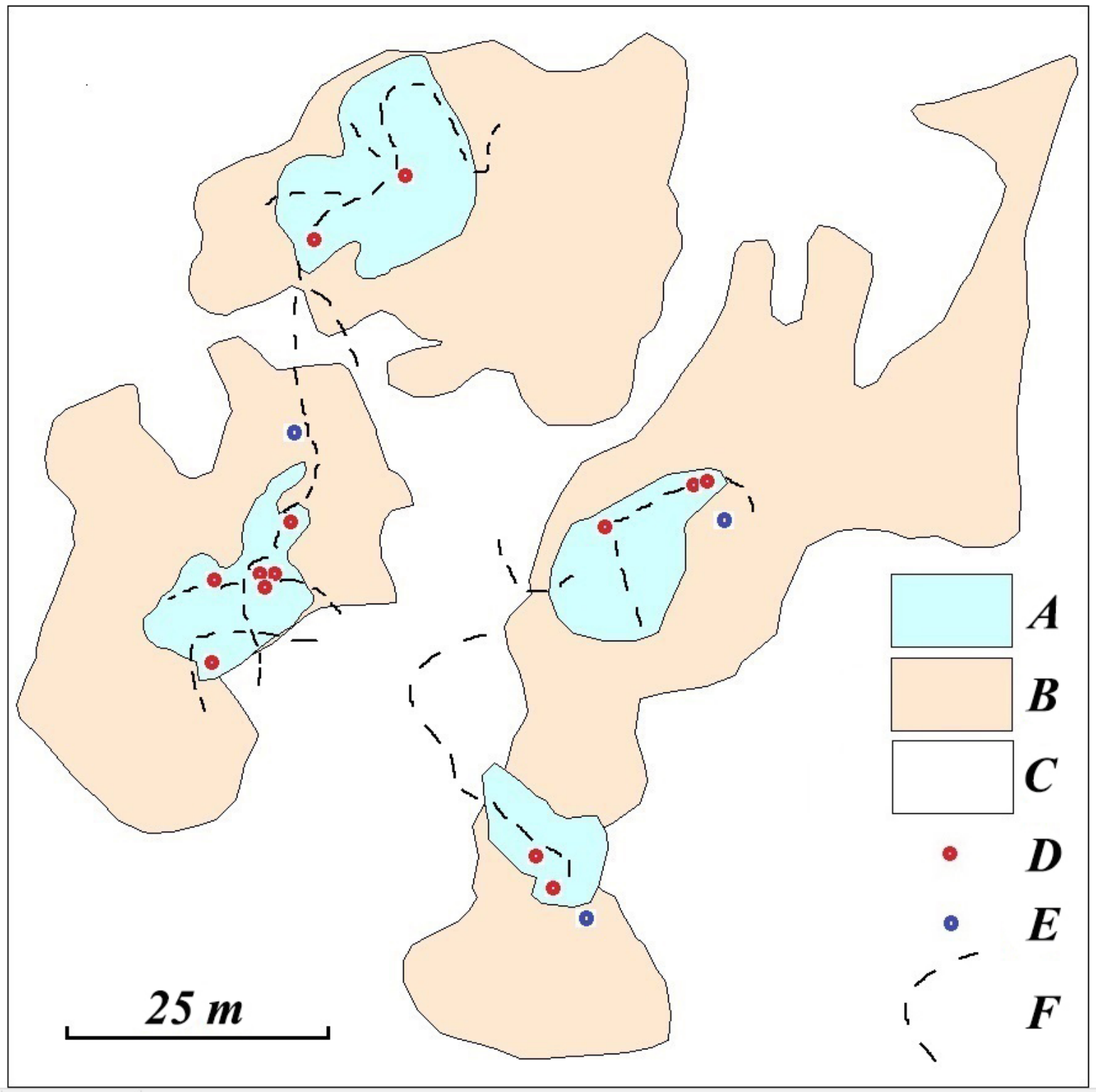

Fig. 6. Mosaic of herbaceous cover on the badger settlement and its surroundings. Legend:

$A$ - the first zone with a predominance of meadow and nemoral vegetatively immobile plants of the ruderal group (Alliaria petiolata, Geranium robertianum, Lactuca serriola, Moehringia trinervia, Polygonum convolvulus); $\mathrm{B}$ - the second zone with a predominance of nemoral vegetatively mobile plants of the ruderal group (Galium odoratum, Glechoma hederacea, Stellaria holostea); C - the third zone with a predominance of nemoral vegetatively mobile plants of the competitive group (Aegopodium podagraria, Carex pilosa, Convallaria majalis); D - active setts; $E$ - abandoned setts; $F$ - paths

The first and second zones are significantly modified by badgers, as they are most actively used throughout the existence of the settlement. The third zone is used less frequently. However, even here, traces of the badger's life activity can be observed. All three zones differ significantly in terms of plant species composition, their abundance, dominance and ecological-coenotic struc- 
ture and, as a result, in the prevailing microgroups of grasses. In the following section, we well discuss these differences in more detail.

The first zone. This zone is represented by well-foot-worn areas with a system of setts with fresh and old mounds of spoil origin (Fig. 4, 7). The closure of the tree stand is low, as mentioned above, making it an ideal place for badgers to rest, bask in the sun, waddle from side to side, clean both partner's and own fur, play and raise their offspring [91, 92]. Besides, this area includes game spots and wide paths connecting the sett entrances. The area of the first zone, which is the actual settlement (complex), covers $1,000 \mathrm{~m}^{2}$. It accounts for $15 \%$ of the herbaceous cover area significantly disturbed by badgers (Fig. 6, $A$ ).

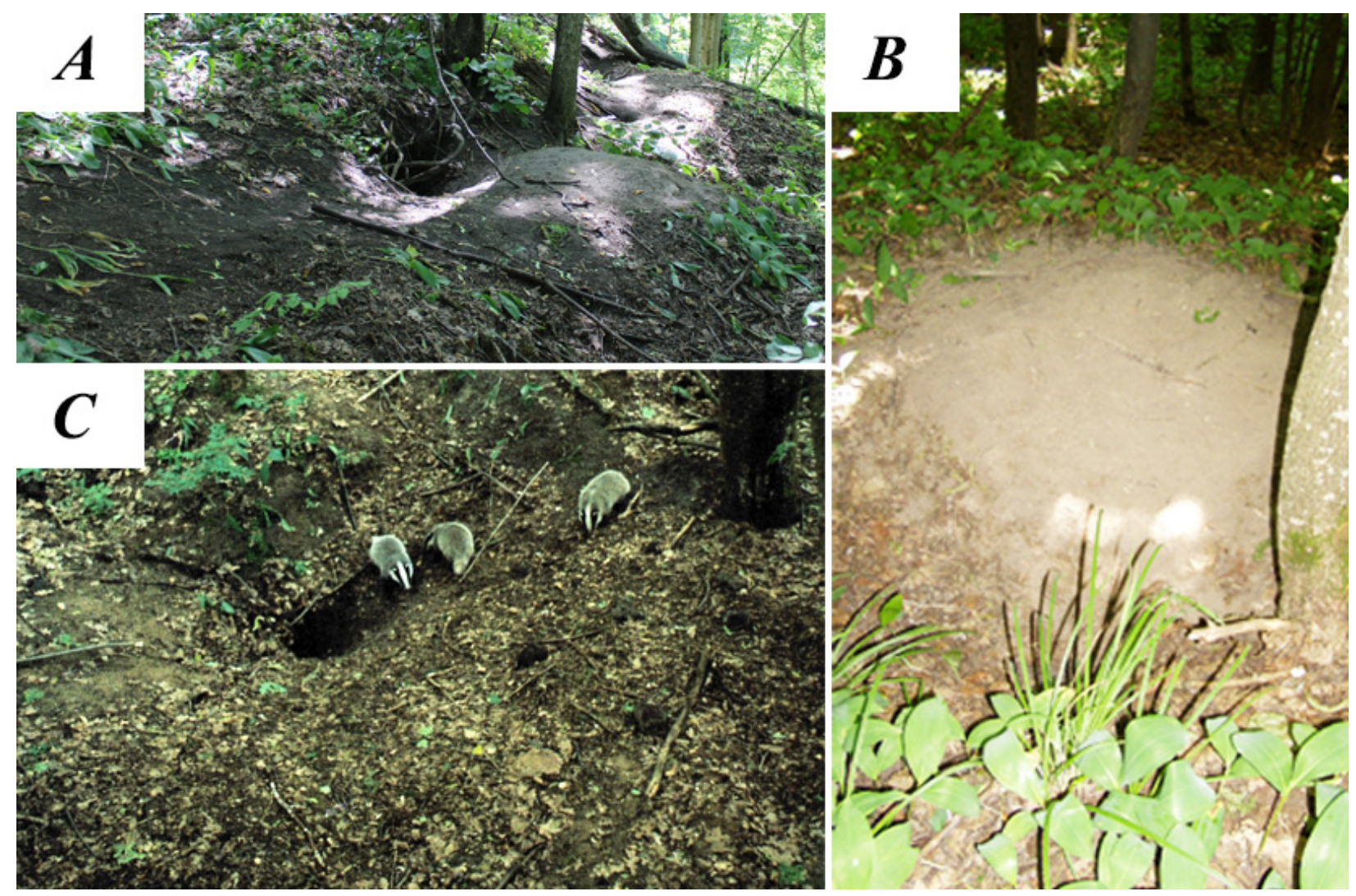

Fig. 7. The first zone of vegetation: $A$ - a foot-worn mound of soil and a path near an active hole. Image courtesy of $\mathrm{O}$. V. Solonina; $B$ - playing field, as well as a place for resting and grooming; $\mathrm{C}$ - badger cubs near a hole in search of soil invertebrates. Image courtesy of E. F. Sitnikova

Active use of sites and paths with compacted soil with poor gas exchange and low water capacity affects the herbaceous cover. In these conditions, the grass survival rate is low and grass closure is extremely low, amounting only to $1-2 \%$. Species density of the groups is small and amounts on average to 3.3 species per $1 \mathrm{~m}^{2}$. However, species richness shows the highest values: 19 species of vascular plants were found in this zone (Table 4). Herbs belong to different ecological-coenotic groups, i.e. meadow, nemoral, black-alder and piny groups. Thereat, more meadow species obviously prevail (Table 5). Meadow species include Achillea millefolium, Anthriscus sylvestris, Chelidonium majus, Clinopodium vulgare, Convolvulus arvensis, Fragaria vesca, Hypericum perforatum, Lactuca serriola, Leonurus quinquelobatus, Polygonum convolvulus, Rorippa sylvestris, Taraxacum officinale, and Viola canina (Table 6). The presence of these species is associated with the badger. Seeds could have been partially transported via epizoochory on paws together with loam and on fur and via endozoochory in digestive tracts. The nearest meadow is located $100 \mathrm{~m}$ away from the badgers' settlement. Another part of the seeds was apparently transported by animals with the grass bundles (rolls) which were collected in a forest clearing $30 \mathrm{~m}$ away from the sett. To recap, badgers first dry the grass and then use it as bedding in their sleeping chambers or to block the sett entrances before hibernation. Some seeds fall off during drying. Only four nemoral plant species were found here: Alliaria petiolata, Geranium robertianum, Geum urbanum and Moehringia trinervia. The piny and black-alder groups include only one type each, i.e. Rubus idaeus and Urtica dioica (see Table 6). It is known that raspberries are a favourite food of badgers [44], whereas nettles attract badgers because of their high contents of proteins and vitamins [93]. 
Characteristics of the herbaceous layer in different zones of vegetation in the badger settlement and in its surroundings

\begin{tabular}{|c|c|c|c|}
\hline \multirow{2}{*}{ Characteristics of the herbaceous layer } & \multicolumn{3}{|c|}{ Herbaceous layer zones } \\
\hline & First & Second & Third \\
\hline Number of plots of $1 \mathrm{~m}^{2}$ & 14 & 21 & 21 \\
\hline Range of the herbaceous layer cover, $\%$ & $1-2$ & $5-30$ & $65-85$ \\
\hline Average cover of the grass layer, $\%, M \pm m_{M}$ & $1.4 \pm 0.13$ & $14.3 \pm 1.53$ & $72.1 \pm 1.17$ \\
\hline Range of the species number on the plots & $1-5$ & $2-6$ & $1-8$ \\
\hline Species density, $M \pm m_{M}$ & $3.3 \pm 0.34$ & $4.3 \pm 0.27$ & $4.9 \pm 0.42$ \\
\hline Mann-Whitney test, value, $U$ & \multicolumn{2}{|c|}{$85(p=0.0368)$} & \\
\hline Mann-Whitney test, value, $U$ & \multicolumn{3}{|c|}{$71(p=0.0110)$} \\
\hline Mann-Whitney test, value, $U$ & & \multicolumn{2}{|c|}{$183(p=0.34551)$} \\
\hline Species richness & 19 & 16 & 13 \\
\hline
\end{tabular}

Note. $M$ is the arithmetic mean, $m_{M}$ is the arithmetic mean error. $p$ is the significance value of differences in species density, significant differences are marked in bold

Number and proportion (\%) of species in different ecological-coenotic groups

in the herbaceous cover of various vegetation zones in the settlement of badgers

\begin{tabular}{|l|c|c|c|}
\hline \multirow{2}{*}{ Ecologico-cenotic groups } & \multicolumn{3}{|c|}{ Herbaceous layer zones } \\
\cline { 2 - 4 } & First & Second & Third \\
\hline Meadow & $13(68.4)$ & - & $12(92.3)$ \\
\hline Nemoral & $4(21.0)$ & $16(100.0)$ & $1(7.7)$ \\
\hline Boreal and piny & $1(5.3)$ & - & - \\
\hline Black-alder & $1(5.3)$ & - & - \\
\hline
\end{tabular}

Table 6

Points of occurrence (Roman numerals) and cover-abundance points (Arabic numerals and +) in different zones of herbaceous cover on the badger settlement and its surroundings.

Broad-leaved nemoral forest. ECG - ecological-coenotic groups of plants, TP - types of plant strategies

\begin{tabular}{|c|c|c|c|c|c|}
\hline \multirow{2}{*}{ Plant name } & \multicolumn{3}{|c|}{ Vegetation zones } & \multirow{2}{*}{ ECG } & \multirow{2}{*}{$\mathrm{TP}$} \\
\hline & First & Second & Third & & \\
\hline 1 & 2 & 3 & 4 & 5 & 6 \\
\hline Achillea millefolium L. & $\mathrm{I}(+)$ & - & - & Mea & $\mathrm{T}$ \\
\hline Adoxa moschatellina $\mathrm{L}$. & - & $\mathrm{I}(+)$ & - & $\mathrm{Ne}-\mathrm{Fo}$ & $\mathrm{R}$ \\
\hline Aegopodium podagraria L. & - & II $(+)$ & III $(+-5)$ & $\mathrm{Ne}-\mathrm{Fo}$ & $\mathrm{C}$ \\
\hline Alliaria petiolata (Bieb.) Cavara \& Grande & II $(+)$ & - & - & Ne-Fo & $\mathrm{R}$ \\
\hline Anthriscus sylvestris (L.) Hoffm. & $\mathrm{I}(+)$ & - & - & Mea & $\mathrm{R}$ \\
\hline Asarum europaeum L. & - & III $(+-1)$ & III $(+-1)$ & $\mathrm{Ne}-\mathrm{Fo}$ & $\mathrm{T}$ \\
\hline Campanula trachelium L. & - & $\mathrm{I}(+)$ & - & $\mathrm{Ne}-\mathrm{Fo}$ & $\mathrm{T}$ \\
\hline Carex digitata $\mathrm{L}$. & - & $\mathrm{I}(+)$ & - & $\mathrm{Ne}-\mathrm{Fo}$ & $\mathrm{T}$ \\
\hline Carex pilosa Scop. & - & III $(+)$ & III $(+-5)$ & $\mathrm{Ne}-\mathrm{Fo}$ & $\mathrm{C}$ \\
\hline Chelidonium majus L. & III $(+)$ & - & - & Mea & $\mathrm{R}$ \\
\hline Clinopodium vulgare L. & $\mathrm{I}(+)$ & - & - & Mea & $\mathrm{R}$ \\
\hline Convallaria majalis L. & - & II $(+-1)$ & III $(1-4)$ & $\mathrm{Ne}-\mathrm{Fo}$ & $\mathrm{C}$ \\
\hline Convolvulus arvensis L. & $\mathrm{I}(+)$ & - & - & Mea & $\mathrm{R}$ \\
\hline Cystopteris fragilis (L.) Bernh. & - & $\mathrm{I}(+)$ & - & $\mathrm{Ne}-\mathrm{Fo}$ & $\mathrm{T}$ \\
\hline Dryopteris filix-mas (L.) Schott & - & $\mathrm{I}(+)$ & - & $\mathrm{Ne}-\mathrm{Fo}$ & $\mathrm{T}$ \\
\hline Fragaria vesca L. & $\mathrm{I}(+)$ & - & - & Mea & $\mathrm{R}$ \\
\hline Galium odoratum (L.) Scop. & - & III $(+-2)$ & III $(+-2)$ & Ne-Fo & $\mathrm{R}$ \\
\hline Geranium robertianum L. & $\mathrm{I}(+)$ & - & - & $\mathrm{Ne}-\mathrm{Fo}$ & $\mathrm{R}$ \\
\hline Geum urbanum L. & III $(+)$ & - & - & $\mathrm{Ne}-\mathrm{Fo}$ & $\mathrm{T}$ \\
\hline Glechoma hederacea L. & - & IV $(+-2)$ & III $(+-2)$ & $\mathrm{Ne}-\mathrm{Fo}$ & $\mathrm{R}$ \\
\hline Hypericum perforatum L. & $\mathrm{I}(+)$ & - & - & Mea & $\mathrm{T}$ \\
\hline Lactuca serriola $\mathrm{L}$. & $\mathrm{I}(+)$ & - & - & Mea & $\mathrm{R}$ \\
\hline Leonurus quinquelobatus Gilib. & $\mathrm{I}(+)$ & - & - & Mea & $\mathrm{R}$ \\
\hline Maianthemum bifolium (L.) F. W. Schmidt & - & - & $\mathrm{I}(+)$ & Bo-Fo & $\mathrm{T}$ \\
\hline Mercurialis perennis L. & - & II $(+)$ & III $(+-2)$ & $\mathrm{Ne}-\mathrm{Fo}$ & $\mathrm{C}$ \\
\hline
\end{tabular}


End of Table 6

\begin{tabular}{|l|c|c|c|c|c|}
\hline \multicolumn{1}{|c|}{1} & 2 & 3 & 4 & 5 & 6 \\
\hline Moehringia trinervia (L.) Clairv. & $\mathrm{I}(+)$ & - & - & $\mathrm{Ne}-\mathrm{Fo}$ & $\mathrm{R}$ \\
\hline Paris quadrifolia L. & - & - & $\mathrm{I}(+)$ & $\mathrm{Ne}-\mathrm{Fo}$ & $\mathrm{T}$ \\
\hline Polygonatum multiflorum (L.) All. & - & $\mathrm{II}(+-1)$ & $\mathrm{II}(+-3)$ & $\mathrm{Ne}-\mathrm{Fo}$ & $\mathrm{T}$ \\
\hline Polygonum convolvulus L. & $\mathrm{I}(+)$ & - & - & $\mathrm{Mea}$ & $\mathrm{R}$ \\
\hline Pulmonaria obscura Dumort. & - & $\mathrm{III}(+)$ & $\mathrm{III}(+-1)$ & $\mathrm{Ne}-\mathrm{Fo}$ & $\mathrm{T}$ \\
\hline Rorippa sylvestris (L.) Bess. & $\mathrm{I}(+)$ & - & - & $\mathrm{Mea}$ & $\mathrm{R}$ \\
\hline Rubus idaeus L. & $\mathrm{I}(+)$ & - & - & Bo-FE & $\mathrm{R}$ \\
\hline Stellaria holostea L. & - & $\mathrm{II}(+-2)$ & $\mathrm{II}(+-1)$ & $\mathrm{Ne}-\mathrm{Fo}$ & $\mathrm{R}$ \\
\hline Taraxacum officinale Wigg. & $\mathrm{I}(+)$ & - & - & $\mathrm{Mea}$ & $\mathrm{R}$ \\
\hline Urtica dioica L. & $\mathrm{III}(+)$ & - & - & $\mathrm{BA}-\mathrm{Fo}$ & $\mathrm{R}$ \\
\hline Viola canina L. & $\mathrm{I}(+)$ & - & - & $\mathrm{Mea}$ & $\mathrm{R}$ \\
\hline Viola mirabilis L. & - & $\mathrm{II}(+)$ & $\mathrm{I}(+)$ & $\mathrm{Ne}-\mathrm{Fo}$ & $\mathrm{T}$ \\
\hline Number of species & 19 & 16 & 13 & 37 & 37 \\
\hline
\end{tabular}

Note. ECG (ecological-coenotic groups): Ne-Fo - nemoral-forest, Bo-Fo - boreal forest, Bo-FE - boreal-forest edge (piny), Mea - Meadow, BA-Fo - black-alder-forest. TP (type of plant strategy): C - competitive, R - ruderal, T - phytocenotically tolarant

Well-worn areas and trails are dominated by ruderal species (Fig. 8, I). These are poorly competitive plants, and their existence in the community depends on disturbances of the herbaceous cover [24] caused by setting animals, including badgers. Ruderal species belong to two groups. The first group includes perennial vegetatively mobile plants, i.e. Convolvulus arvensis, Fragaria vesca, Rubus idaeus, Urtica dioica, among others. They are represented by singular plants, which, in case of trampling, are able to quickly capture the territory due to their high vegetative mobility (Fig. 10, $A$ ). The second group is formed by annual and biennial vegetatively immobile grasses such as Alliaria pet- iolata, Geranium robertianum, Lactuca serriola, Moehringia trinervia and Polygonum convolvulus. These plants show no vegetative growth and reproduction at all. However, they have a complex of biological features of the "nomad ${ }^{5}$ type" (as termed by Denslow [94]). It is aimed at rapid reclamation of disturbances and quick transition to the latent state. Nomad plants form a stock of seeds in the soil [95]; they have a high seed productivity, a long germination period and high rates of development. They are unable to pass to the quasi-senile state and secondary dormancy. These species do not retain a territory for longer than 1 year [24].

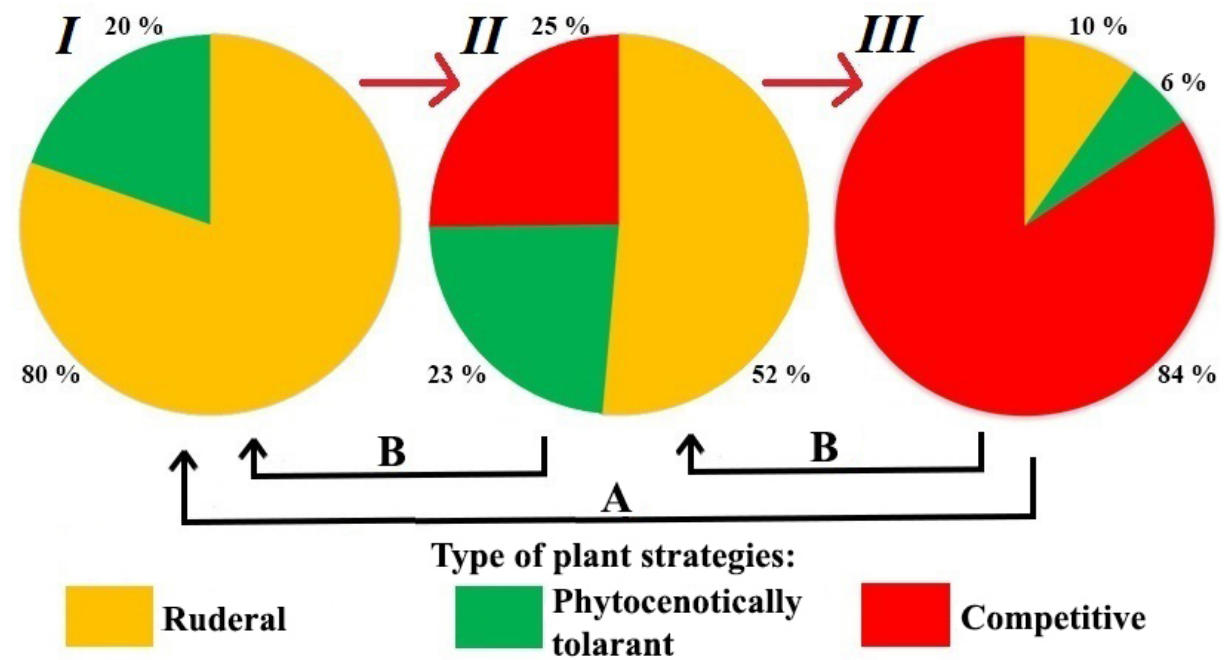

Fig. 8. Cyclic development of microgroups of herbaceous cover on badger settlements and in the surroundings. Types of microgroups: I - with a predominance of meadow and nemoral vegetatively immobile plants of the ruderal group (Alliaria petiolata, Geranium robertianum, Lactuca serriola, Moehringia trinervia, and Polygonum convolvulus); II - with a predominance of nemoral vegetatively mobile plants of the ruderal group (Galium odoratum, Glechoma hederacea, and Stellaria holostea); III - with a predominance of nemoral vegetatively mobile plants of the competitive group (Aegopodium podagraria, Carex pilosa, and Convallaria majalis). Red arrows show the direction of microgroup development determined by competitive plants. Black arrows show the directions of microgroup transformations determined by badgers. Development cycles: A - extended, B - shortened

${ }^{5}$ Nomad, i.e. associated with relocation [96]. 
Second zone. The second zone is directly adjacent to the first zone, to the foot-worn areas with setts, and is a site where badgers actively feed (Fig. 6, B). For example, it is the zone where a female badger with cubs forages constantly, since the brood mostly stays near the sett all summer and autumn $[91,97]$. Other members of the family also feed during the daily rest [42]. Some zoologists argue that badgers try to forage right near the settlement, just 150-200 m away, for 2-3 weeks before hibernation and after hibernation in spring [47]. When extracting soil invertebrates and small mouse-like rodents, as well as when digging up roots, rhizomes, tubers and bulbs, badgers make a large number of digs, loosen the litter and soil layers lying below. Disturbances created by badgers in this zone amount to $70-95 \%$ in total (Fig. 9). Loosening reduces the bulk density of soil and increases its fertility, and such soil has increased temperature and improved gas exchange as well as an increased intensity of microbiological processes and an increased availability of nutrients for plants $[98,99]$. The area of the second zone covers $5,500 \mathrm{~m}^{2}$ and accounts for $85 \%$ of the area of the herbaceous cover significantly disturbed by badgers (see Fig. 6, $B$ ).

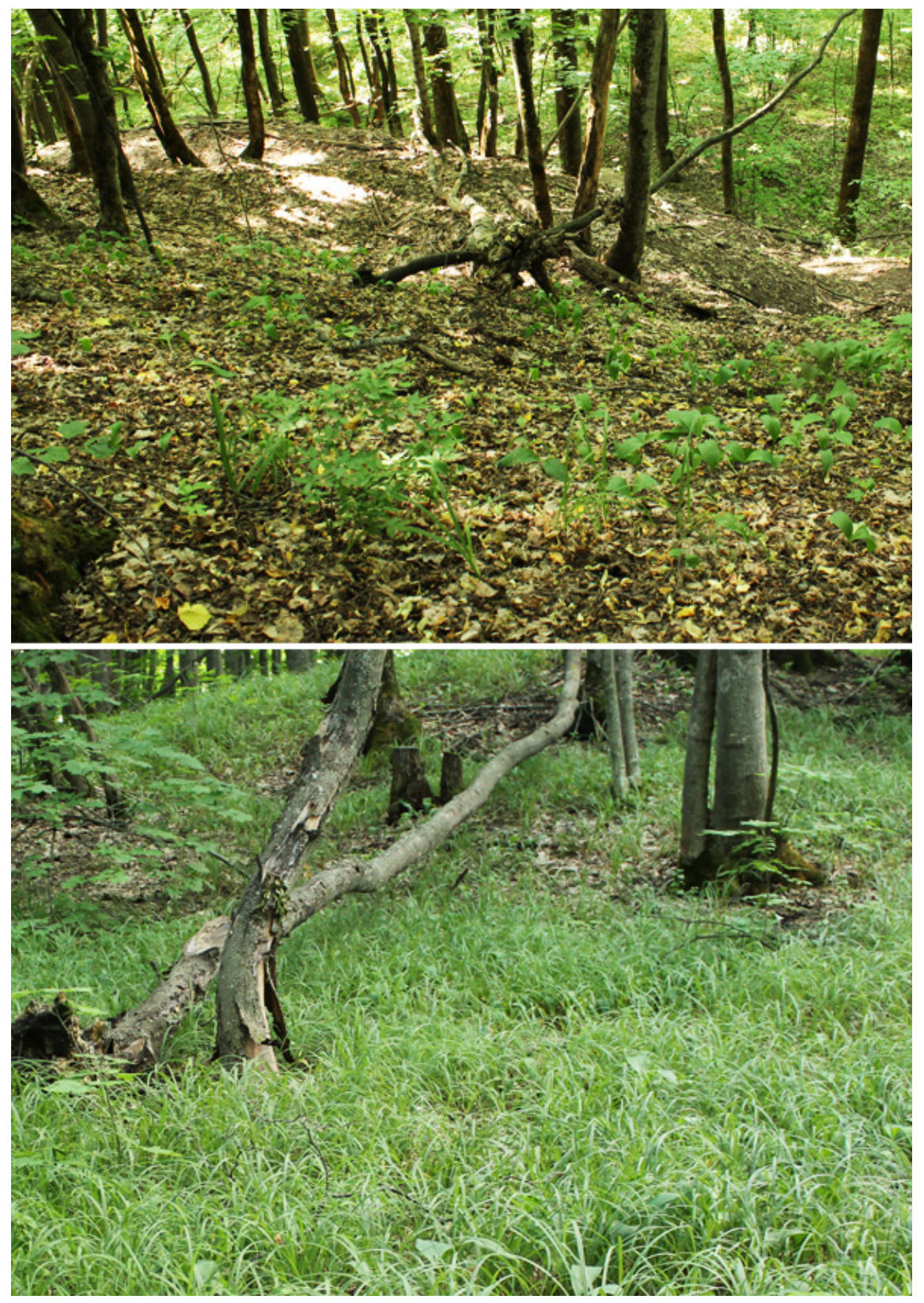

Fig. 9. Herbaceous cover around a settlement of the European badger. The top photo is of the second zone. The herbaceous cover is badly damaged by badgers. Phytocoenotically tolerant plants predominate, i.e. vegetatively immobile spring vetch (Lathyrus vernus) and wood avens (Geum urbanum), vegetatively poorly mobile Solomon's seal (Polygonatum multiflorum), etc. The bottom photo is of the third zone. The herbaceous cover is slightly damaged by badgers. Vegetatively mobile plants of the competitive group, mainly pilose sedge (Carex pilosa), dominate. Image courtesy of O. V. Solonina 
Active setting activity of the animals results in the formation of microgroups, with a relatively low projective cover from 5 to $30 \%$. Species richness of vascular plants is lower in comparison with the first zone (see Table 4). There are no lightdemanding meadow or piny species (see Table 5), mainly due to the shading of the herbaceous cover, which is located under the closed canopy of a stand of Acer platanoides, Tilia cordata and others. All 16 discovered species were shade-tolerant grasses of the nemoral group. At the same time, the species density of the second-zone microgroup is significantly higher than that of the first one (see Table 4).

In the second zone, ruderal species are still dominant (Fig. 8, II). However, this group has no annuals or biennials, and the greatest coenotic significance is shown by vegetatively mobile plants, i.e. Galium odoratum, Glechoma hederacea and Stellaria holostea (see Table 6). They are characterised by the highest occurrence and cover points and quickly recover from disturbances caused by badgers due to high vegetative mobility. Bedstraw, ground ivy and stitchwort differ from ruderal "nomad" species by a longer (over 2 years) duration of the territory retention [24]. Notably, tolerant plants, with Asarum europaeum, Polygonatum multiflorum, Pulmonaria obscura and Viola mirabilis, sometimes Campanula trachelium, Carex digitate, Cystopteris fragilis and Dryopteris filixmas as typical components of the herbaceous cover, demonstrate maximum participation in this zone. At the same time, all competitive broadleaved grass species are found in the community, i.e. Aegopodium podagraria, Carex pilosa, Convallaria majalis and Mercurialis perennis. However, their participation is minimal (see Table 6).

The third zone. It is usually located beyond the second zone, sometimes directly adjacent to the first zone (Fig. 6, C). Here, badgers also dig and loosen the soil for food. However, the intensity of the impact on the herbaceous cover is not as high as in the second zone. Disturbances created by the animals here only account for $15-35 \%$.

This part of the coenosis enjoys a relatively large herbaceous cover of 65-85\% (see Fig. 9), mainly because as the setting activity of animals decreases, competitive plants of the nemoral group start to dominate, i.e. Aegopodium podagraria, Carex pilosa and Convallaria majalis (see Table 5,6). They are characterised by high vegetative mobility and productivity, large biomass and a significant duration of the territory retention [24]. This allows the competitive plants to create coenotically isolated thickets that displace weak competitive species
(Fig. 8, III). Therefore, Adoxa moschatellina, Campanula trachelium, Carex digitata, Cystopteris fragilis and Dryopteris filix-mas are not found in this zone. In addition, it is difficult for new species to enter these groups. Only isolated individuals of extremely tolerant plants appear, i.e. Maianthemum bifolium and Paris quadrifolia. The participation of small grasses in the community is minimal, and these species show a low level of vitality and are in low numbers (see Table 6). As a result, species richness amounts only to 13 species. Species density of the herbaceous cover is, however, similar to that of the second zone (see Table 4).

The vegetation of the zones and their borders is dynamic and changes over time. This is due to the fact that badgers sometimes abandon part of their setts or the entire settlement for several years [50]. Zoologists believe that the disappearance of animals is caused by the reduction in their numbers as a result of epizootic and other diseases [7]. Gorshkov believes that badgers can be forced out from the territory by wild boars, who compete with badgers for food, destroy their setts and kill their cubs [42]. Sometimes, animals leave the inhabited place because of a strong infection with ectoparasites [37]. Currently, overhunting and poaching are the main reasons for a decline in badger populations. First, the well-foot-worn areas and paths in front of the setts (the first zone) and the adjacent second zone in abandoned settlements become completely overgrown with ruderal mobile grasses within 3 to 4 years (Fig. 10, $A-C$ ), followed by an overgrowth with competitive grasses (see Fig. 8; Fig. 10, D). When the badger population increases, the animals return to the abandoned sett, renovate it and disturb this unidirectional microsuccession in the herbaceous cover. Thus, extended and shortened cycles of vegetation development are formed. Extended cycles of microgroups are formed if badgers return to a sett at the stage of overgrowing with competitive grasses (see Fig. 10, D). Shortened cycles occur if they return during the sett's overgrowing with vegetatively mobile species of the ruderal group (see Fig. 10, $A-C$ ) or if badgers create small bare spots in between competitive plants that are then quickly replaced by ruderal species (see Fig. 8).

A survey of badger settlements has shown that the foraging activity of this animal continuously creates a mosaic pattern of herbaceous cover and forms a multi-species community of vascular plants. Spatial redistribution of microgroups dominated by different types of plant strategies (ruderal, tolerant or competitive) help to maintain this diversity. 

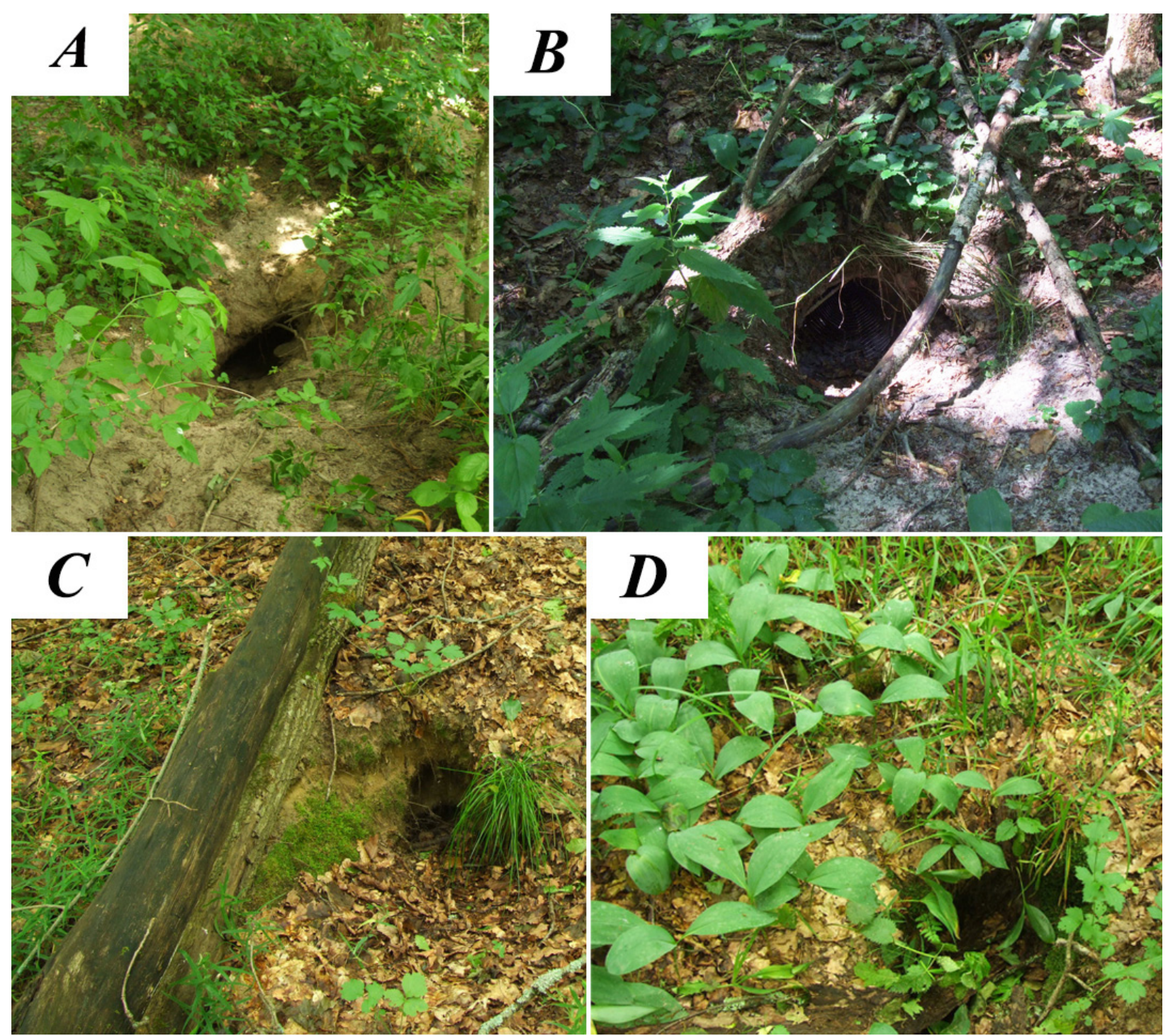

Fig. 10. Abandoned setts of the European badger at different stages of overgrowing with herbaceous cover: A - microgroup of plants with a predominance of ruderal vegetatively mobile common nettle (Urtica dioica) and red raspberry (Rubus idaeus); B - microgroup of plants with a predominance of ruderal vegetatively mobile common nettle (Urtica dioica) and ground-ivy (Glechoma hederacea); C - microgroup of plants with a predominance of ruderal vegetatively mobile greater stitchwort (Stellaria holostea) and tolerant vegetatively immobile wood avens (Geum urbanum); tufted hairgrass (Deschampsia cespitosa) grows near the sett; $D$ - microgroup with a predominance of nemoral vegetatively mobile plants of the competitive group - pilose sedge (Carex pilosa) and lily of the valley (Convallaria majalis). Image courtesy of E. F. Sitnikova

\section{Conclusion}

The composition of plant feeds shows that the badger is involved in creating both intracoenotic and intercoenotic flows of plant diaspores. This is evidenced by the presence of plants of different communities in its diet, i.e. forest, meadow, swamp and water plants. The badger can move plant diaspores in three ways: via endozoochory, epizoochory and synzoochory. That is why seeds of the largest possible number of plant species with various adaptations to zoochory are involved in diaspore flows. Literature analysis has shown that badgers can move large amounts of diaspores over a distance of 1 kilometre and smaller amounts up to 2 or 3 kilometres. Foraging and construction activities of this animal contribute to a significant increase in the species diversity of vascular plants within settlements. Badgers change the ecologicalcoenotic composition of the community, the flora becomes mixed. Forest, meadow, black-alder, boreal and piny plant species begin to co-dominate in the herbaceous cover of nemoral forests.

While foraging, the badger actively creates a mosaic pattern of the herbaceous cover over the entire area of the family plot, which is several hundred hectares. This mosaic is represented by three variants of microgroups: 1) with a predominance of vegetatively immobile annuals and biennials of 
the ruderal group; 2) with a predominance of vegetatively mobile perennials of the ruderal groups and with significant participation of phytocoenotically tolerant plants; 3) with a predominance of vegetatively mobile perennials of the competitive group. This sequence of microgroups alternating over time represents a microsuccession. Competitive species are the driving force behind the development of these groups. They gradually crowd out rudearal and tolerant plants and can become dominant in the herbaceous cover for a long time. However, badgers' use of the community territory on a "shift" basis occasionally interrupts these unidirectional microsuccessions. In this case, extended and shortened cycles of microgroup development are formed. Extended cycles are formed if badgers dig through thickets of competitive plants over a large area to minimise the closure of the herbaceous cover. Shortened cycles can be formed if foraging animals return to their previously dug areas 2 or 3 years later, during the domination of vegetatively mobile grasses of the ruderal group. In this case, the stage with a predominance of competitive plants is omitted. The multi-species composition of the herbaceous cover is maintained by the disturbances caused by badgers and cyclic microsuccessions. The mechanism for maintaining this diversity is based on the spatial redistribution of microgroups dominated by plant species with different strategies.

These facts indicate that in an undisturbed biocoenosis, badgers were edificators of the herbaceous cover and played an active part in the formation and maintenance of the mixed nature of the community flora. Besides, they contributed to the restoration of the species diversity of the coenoses that were lost as a result of the destructive human impact. However, due to overhunting and persistent persecution by poachers, this species has recently become extremely rare and endangered and has ceased active transformation of the environment.

\section{Библиографический список}

1. Восточноевропейские леса: история в голоцене и современность / отв. ред. О. В. Смирнова. - Москва : Наука, 2004. - Кн. 1. -479 с.

2. Восточноевропейские широколиственные леса / под ред. О. В. Смирновой. - Москва : Наука, 1994. - 364 с.

3. Евстигнеев, О. И. Механизмы поддержания биологического разнообразия лесных биогеоценозов : дис. ... д-ра биол. наук / Евстигнеев О. И. - Н. Новгород, 2010. - 513 с.

4. Евстигнеев, О. И. Зубр и поддержание биоразнообразия лугов (на примере заповедника «Брянский лес») / О. И. Евстигнеев, О. В. Солонина // Бюллетень Московского общества испытателей природы. Отдел биологический. - 2016. - Т. 121, вып. 2. - С. 59-65.

5. Красная книга Брянской области. - Брянск : РИО БГУ, 2016. - 432 с

6. Ситникова, Е. Ф. Млекопитающие заповедника «Брянский лес» / Е. Ф. Ситникова, А. В. Мишта // Фауна позвоночных животных заповедника «Брянский лес» (птицы, млекопитающие). - Брянск : Десяточка, 2008. C. $50-84$.

7. Млекопитающие Советского Союза / В. Г. Гептнер, Н. П. Наумов, П. Б. Юргенсон, А. А. Слудский, А. Ф. Чиркова, А. Г. Банников. - Москва : Высшая школа, 1967. - Т. 2. - 1004 с.

8. Лобачев, Ю. С. Экология барсука в горах юго-востока Казахстана / Ю. С. Лобачев // Бюллетень Московского общества испытателей природы. Отдел биологический. - 1976. - Т. 80, вып. 5. - С. 7-21.

9. Лихачев, Г. Н. Некоторые черты экологии барсука в широколиственном лесу Тульских засек / Г. Н. Лихачев // Сборник материалов по результатам изучения млекопитающих в государственных заповедниках. Москва : Минсельхоз СССР, 1956. - С. 72-94.

10. Строганов, С. У. Звери Сибири. Хищные / С. У. Строганов. - Москва : АН СССР, 1962. - 458 с.

11. Горшков, П. К. К вопросу о значении барсука в лесных биоценозах Волжско-Камского края / П. К. Горшков // Природные ресурсы Волжско-Камского края, животный мир. - Казань : Изд-во Казанского ун-та, 1964. - Вып. 1. - С. 46-52.

12. Барабаш, Л. А. Экология барсука, корсака и лисицы в Северной Кулунде / Л. А. Барабаш, В. В. Шибанов // Биотехнология. Теоретические основы и практические работы в Сибири. - Новосибирск : Наука, 1980. C. $197-216$.

13. Болысов, С. И. Биогенное рельефообразование на суше. Зональность / С. И. Болысов. - Москва : Геос, 2007. - T. 2. $-466 \mathrm{c}$.

14. Анималистика Алексея Субботина. - 2013. - URL: http://www.aleksey-subbotin.ru/index.html

15. Растительность Европейской части СССР. - Ленинград : Наука, 1980. - 429 с.

16. Федотов, Ю. П. Некоторые участки, важные для сохранения степных видов растений в Брянской области / Ю. П. Федотов // Изучение и охрана биологического разнообразия Брянской области. - Трубчевск : Заповедник «Брянский лес», 2005. - Вып. 1. - С. 8-17.

17. Кузнецов, Б. А. Очерк зоогеографического районирования СССР / Б. А. Кузнецов. - Москва : Изд-во МГУ, 1950. $-176 \mathrm{c}$.

18. Миркин, Б. М. Словарь понятий и терминов современной фитоценологии / Б. М. Миркин, Г. С. Розенберг, Л. Г. Наумова. - Москва : Наука, 1989. - 223 с. 
19. Маевский, П. Ф. Флора средней полосы Европейской части России / П. Ф. Маевский. - Москва : Т-во научных изданий КМК, 2006. - 600 с.

20. Ханина, Л. Г. Методика оценки и анализа разнообразия растительного покрова заповедников / Л. Г. Ханина, Л. Б. Заугольнова, В. Э. Смирнов, Е. М. Глухова // Оценка и сохранение биоразнообразия лесного покрова в заповедниках Европейской России / под ред. Л. Б. Заугольновой. - Москва : Научный мир, 2000. C. $30-45$.

21. Ниценко, А. А. Об изучении экологической структуры растительного покрова / А. А. Ниценко // Ботанический журнал. - 1969. - Т. 54 (7). - С. 1002-1014.

22. Смирнов, В. Э. Обоснование системы эколого-ценотических групп видов растений лесной зоны Европейской России на основе экологических шкал, геоботанических описаний и статистического анализа / В. Э. Смирнов, Л. Г. Ханина, М. В. Бобровский // Бюллетень Московского общества испытателей природы. Отдел биологический. - 2006. - Т. 111, вып. 2. - С. 36-46.

23. Смирнова, О. В. Анализ фитоценотических потенций некоторых древесных видов широколиственных лесов Европейской части СССР / О. В. Смирнова, А. А. Чистякова // Журнал общей биологии. - 1980. - Т. 41, № 3. - С. 350-362.

24. Смирнова, О. В. Структура травяного покрова широколиственных лесов / О. В. Смирнова. - Москва : Наука, 1987. - 208 с.

25. Хитрово, В. Н. О парусности зачатков некоторых растений (материалы для учета скорости распространения растений) / В. Н. Хитрово // Записки Киевского общества естествоиспытателей. - Киев : Тип. Императорского ун-та Св. Владимира, 1910. - Т. 10, вып. 3. - С. 251-274.

26. Ильинский, А. П. Расселение растений (основные понятия и термины) / А. П. Ильинский // Природа. 1945. - № 5. - С. 45-55.

27. Левина, Р. Е. Способы распространения плодов и семян / Р. Е. Левина. - Москва : Изд-во МГУ, 1957. - 358 с.

28. Левина, Р. Е. Морфология и экология плодов / Р. Е. Левина. - Ленинград : Наука, 1987. - 160 с.

29. Юргенсон, П. Б. Барсук. Пушные звери / П. Б. Юргенсон. - Москва : Внешторгиздат, 1932. - 28 с.

30. Евстигнеев, О. И. Неруссо-Деснянское полесье: история природопользования / О. И. Евстигнеев. - Брянск : Десяточка, 2009. - 139 с.

31. Ивантер, Э. В. К изучению барсука на северном пределе ареала / Э. В. Ивантер // Труды государственного заповедника «Кивач». - Петрозаводск : Карелия, 1973. - С. 164-173.

32. Жарков, И. В. Материалы по питанию барсука (Meles meles L.) в Татарской республике / И. В. Жарков, В. П. Теплов // Работы Волжско-Камской зональной охотничье-промысловой биологической станции. - 1932. - Вып. 2. - С. 110-124.

33. Алгульян, С. Г. Питание и сезонные особенности образа жизни крымского барсука (Meles meles Tauricus Ogn.) / С. Г. Алгульян // Зоологический журнал. - 1940. - Т. 19, № 3. - С. 499-508.

34. Саввина, М. И. Барсук в Крымском государственном заповеднике, его биология и распространение / М. И. Саввина // Труды Крымского государственного заповедника. - Москва : Гл. упр. по заповедникам, зоопаркам и зоосадам, 1940. - Вып. 2. - С. 228-250.

35. Брудин, И. Д. Барсуки уничтожают арбузы / И. Д. Брудин // Природа. - 1959. - № 11. - С. 118.

36. Иванова, Г. И. Сравнительная характеристика питания лисицы, барсука и енотовидной собаки в Воронежском заповеднике // Материалы по фауне и экологии животных. - Москва : МГПИ им. В. И. Ленина, 1962. C. 210-256.

37. Корчмарь, Н. Д. Некоторые данные о распространении, биологии и хозяйственном значении барсука в Молдавии / Н. Д. Корчмарь // Вопросы экологии и практического значения птиц и млекопитающих Молдавии. - Кишинев : Штиница, 1962. - Вып. 1. - С. 56-63.

38. Данилов, П. И. Куньи северо-запада СССР / П. И. Данилов, И. Л. Туманов. - Ленинград : Наука, 1976. $356 \mathrm{c.}$

39. Закиров, А. Питание барсука в условиях Пскемского и Чаткальского хребтов / А. Закиров // Узбекский биологический журнал. - 1976. - № 5. - С. 49-50.

40. Смирнов, М. Барсук в Бурятской АССР / М. Смирнов, В. Носков // Охота и охотничье хозяйство. - 1977. № 2. - С. 12-14.

41. Горшков, П. К. Многолетние и сезонные изменения в питании барсука Волжско-Камского госзаповедника / П. К. Горшков // Природные ресурсы Волжско-Камского края, животный мир. - Казань : Изд-во Казанского ун-та, 1978. - Вып. 5. - С. 79-95.

42. Горшков, П. К. Барсук в биоценозах республики Татарстан / П. К. Горшков. - Казань : Табигать, 1997. $176 \mathrm{c}$.

43. Ashby, K. R. The diet of the badger (Meles meles L.) in Castle Dene, Country Durham / K. R. Ashby, K. Elliot // Acta Zool. Fennica. - 1983. - Vol. 174. - P. 205-207.

44. Бородин, П. Л. Сравнительная экология барсука, лисицы, енотовидной собаки и их биоценотическое значение в Мордовском заповеднике : дис. ... канд. биол. наук / Бородин П. Л. - Москва, 1984. - 271 с.

45. Шибанов, В. В. Барсук (Meles meles L.), корсак (Vulpes carsac L.) и лисица (Vulpes vulpes L.) БарабинскоКулиндинской низменности (экология, этология, биоценотическое и практическое значение) : автореф. дис. ... канд. биол. наук / Шибанов В. В. - Новосибирск, 1989. - 23 с.

46. Goszczyński, J. Diet composition of badgers (Meles meles) in a pristine forest and rural habitats of Poland compared to other European populations / J. Goszczyński, B. Jędrzejewska, W. Jędrzejewski // Journ. Zool. - 2000. Vol. 250. - P. 495-505. 
47. Минаков, И. А. Барсук (Meles anakuma Temminck, 1844) в лесостепях восточной части Минусинской котловины (ареал, морфология, экология, ресурсы) : дис. ... канд. биол. наук / Минаков И. А. - Красноярск, 2004. - 155 c.

48. Дикий, I. Живлення борсука (Meles meles L.) на території Західної України / I. Дикий, О. Дика // Науковий вісник Ужгородського університету. Сер.: Біологія. - 2005. - Вип. 17. - С. 42-49.

49. Соловьев, В. А. Биология и хозяйственное значение барсуков Вятско-Камского междуречья : дис. ... канд. биол. наук / Соловьев В. А. - Киров, 2007. - 162 с.

50. Сидорчук, Н. В. Европейский барсук в Дарвинском заповеднике. Традиционные и новые методы в изучении экологии и поведения норных хищников / Н. В. Сидорчук, В. В. Рожнов. - Москва : Т-во научных изданий КМК, 2010. - 122 с.

51. Загайнова, О. С. Питание барсука (Meles leucurus Hodgson, 1847) в природном парке «Самаровский чугас» (Западная Сибирь) / О. С. Загайнова, Н. И. Марков // Экология. - 2011. - № 5. - С. 373-383.

52. Neal, E. The badger / E. Neal. - London : Collins, 1948. - 155 p.

53. Левина, Р. Е. Репродуктивная биология семенных растений (обзор проблемы) / Р. Е. Левина. - Москва : Наука, 1981. - 96 с.

54. Бородина, М. Н. Млекопитающие Мордовского заповедника (эколого-фаунистический очерк) / М. Н. Бородина, Л. П. Бородин, И. С. Терешкин, Ю. Ф. Штарев // Труды Мордовского государственного заповедника им. П. Г. Смидовича. - 1970. - Вып. 5. - С. 5-60.

55. Положенцев, П. А. К вопросу о лесохозяйственном значении песчаного барсука / П. А. Положенцев, Л. П. Астанин // Труды Башкирского сельскохозяйственного института. - 1942. - Т. 3. - С. $128-138$.

56. Образцов, Б. В. Материалы опытов и наблюдений по распространению дикими животными семян деревьев и кустарников в открытые биотопы лесостепи / Б. В. Образцов // Сообщения лаборатории лесоведения. 1961. - Вып. 3. - С. 69-88.

57. Neal, E. G. The environmental impact of badgers (Meles meles) and their setts / E. G. Neal, T. J. Roper // The environmental impact burrowing animals and animal burrows. - 1991. - № 63. - P. 89-106.

58. Млекопитающие Казахстана. Хищные (куньи, кошки). - Алма-Ата : Наука Казахской ССР, 1982. - Т. 3 , ч. $2 .-263 \mathrm{c}$.

59. Коротков, В. Н. Демутационные процессы в островных лесных массивах (на примере ГИЗЛ «Горки Ленинские» и Каневского заповедника) : автореф. дис. ... канд. биол. наук / Коротков В. Н. - Москва, 1992. - 16 с.

60. Евстигнеев, О. И. Анемохория и дальность рассеивания семян деревьев Восточноевропейских лесов / О. И. Евстигнеев, И. А. Мурашев, В. Н. Коротков // Лесоведение. - 2017. - № 1. - С. 45-52.

61. Евстигнеев, О. И. Зоохория и дальность разноса семян в хвойно-широколиственных лесах Восточной Европы / О. И. Евстигнеев, П. В. Воеводин, В. Н. Коротков, И. А. Мурашев // Успехи современной биологии. 2013. - T. 133, № 4. - С. 392-400.

62. Evstigneev, O. I. Zoochory and peculiarities of forest community formation: a review / O. I. Evstigneev, V. N. Korotkov, I. A. Murashev, P. V. Voevodin // Russian Journal of Ecosystem Ecology. - 2017. - Vol. 2, № 1. - P. 1-16. DOI 10.21685/2500-0578-2017-1-2.

63. Данилов, П. И. Материалы по биологии барсука на северо-западе РСФСР / П. И. Данилов, И. Л. Туманов // Сборник научно-технической информации (охота, пушнина и дичь). - Киров : ВНИИОЗ, 1971. - Вып. 34. C. 25-31.

64. Kowalczyk, R. Daily movement and territory use by badgers Meles meles in białowieźa Primeval Forest, Poland / R. Kowalczyk, A. Zalewski, B. Jędrzejewska // Wildlife biology. - 2006. - Vol. 12, № 4. - P. 385-391.

65. Harlow, H. J. Effect of fasting on rate of food passage and assimilation efficiency in badgers / H. J. Harlow // J. Mamm. - 1981. - Vol. 62, № 1. - P. 173-177.

66. Пажетнов, В. С. Бурый медведь / В. С. Пажетнов. - Москва : Агропромиздат, 1990. - 215 с.

67. Kruuk, H. H. Changes in the Size of Groups and Ranges of the European Badger (Meles meles L.) in an Area in Scotland / H. H. Kruuk, T. Parish // Journ. of Animal Ecology. - 1987. - Vol. 56, № 1. - P. 351-364.

68. Сабдинова, Д. К. Особенности экологии барсука (Meles meles) в Ишимской лесостепи Казахстана : дис. ... канд. биол. наук / Сабдинова Д. К. - Омск, 2005. - 117 с.

69. Евстигнеев, О. И. Сойка (Garrulus glandarius) и зоохория в лесных сообществах (на примере НеруссоДеснянского полесья) / О. И. Евстигнеев, И. А. Мурашев, М. С. Романов // Russian Journal of Ecosystem Ecology. - 2018. - Vol. 3, № 1. - С. 1-18. - DOI 10.21685/2500-0578-2018-1-1.

70. Казакова, М. В. Флора Рязанской области / М. В. Казакова. - Рязань : Русское слово, 2004. -388 с.

71. Формозов, А. Н. Фауна / А. Н. Формозов // Природа города Москвы и Подмосковья. - Москва - Ленинград : АН СCCР, 1947. - C. 287-370.

72. Динесман, Л. Г. Изучение истории биогеоценозов по норам животных / Л. Г. Динесман // Ботанический журнал. - 1968. - Т. 53 (2). - С. 214-222.

73. Лавровский, В. В. Динамика численности поселений барсука Meles meles в Окском заповеднике / В. В. Лавровский // Труды Окского государственного природного биосферного заповедника. - Рязань, 2005. - Вып. 24. - С. 173-182.

74. Ситникова, Е. Ф. Размещение нор барсука (Meles meles) в восточном полесье (Брянская область) / Е. Ф. Ситникова // Динамика популяций охотничьих животных северной Европы : Международный симпозиум. - Петрозаводск, 2010. - С. 174-175. 
75. Roper, T. J. Internal structure and contents of three badger (Meles meles) setts / T. J. Roper, A. I. Tait, D. Fee, S. F. Christian // J. Zool. - 1991. - Vol. 225, № 1. - P. 115-124.

76. Neal, E. G. Badgers / E. G. Neal // Animal of Britain. - 1962. - № 1. -25 p.

77. Евстигнеев, О. И. Сукцессионные процессы в растительном покрове третьей супесчаной террасы НеруссоДеснянского полесья (на примере заповедника «Брянский лес» и окружающих территорий) / О. И. Евстигнеев // Восточноевропейские леса: история в голоцене и современность / отв. ред. О. В. Смирнова. Москва : Наука, 2004. - Кн. 2. - С. 266-278.

78. Бородин, П. Л. Влияние ценозообразующей деятельности барсука на почвообразование под пологом леса / П. Л. Бородин // Эколого-фаунистические исследования в Нечерноземной зоне РСФСР : межвуз. сб. науч. тр. Саранск : Мордовский гос. ун-т, 1983. - С. 5-15.

79. Смирнова, О.В.Популяционная организация ненарушенного биогеоценотического покрова лесных территорий лесного пояса Восточной Европы / О. В. Смирнова // Восточноевропейские леса: история в голоцене и современность. - Москва : Наука, 2004. - Кн. 1. - С. 25-43.

80. Воронов, А. Г. Геоботаника / А. Г. Воронов. - Москва : Высш. шк., 1973. - 384 с.

81. Гиляров, В. Г. Роль степных грызунов в происхождении полевой почвенной энтомофауны и сорнополевой растительности / В. Г. Гиляров // Доклады АН СССР. - 1951. - Т. 79, № 4. - С. 669-671.

82. Быков, Б. А. Геоботаника / Б. А. Быков. - Алма-Ата : АН Казахской ССР, 1953. - 458 с.

83. Биогеоценотический покров Неруссо-Деснянского Полесья: механизмы поддержания биологического разнообразия / О. И. Евстигнеев, В. Н. Коротков, К. В. Беляков, Т. Ю. Браславская, А. М. Романовский, Г. Е. Рубашко, Е. П. Сарычева, Ю. П. Федотов. - Брянск : Заповедник «Брянский лес», 1999. - 176 с.

84. Бородин, П. Л. Биоценотическая оценка деятельности барсука в сосново-широколиственном лесу Мордовского заповедника / П. Л. Бородин // Фауна и экология животных. - Москва : МГПИ им. В. И. Ленина, 1976. - С. $145-156$.

85. Дворников, М. Г. Особенности растительности в поселениях барсука (Meles meles L.) на южном Урале / М. Г. Дворников, Н. П. Дворникова, В. П. Коробейникова // Экология. - 1994. - Т. 5-6. - С. $108-109$.

86. Керзина, М. Н. Влияние вырубок и гарей на формирование лесной фауны / М. Н. Керзина // Роль животных в жизни леса. - Москва : Изд-во МГУ, 1956. - С. 217-304.

87. Звери Ленинградской области (фауна, экология и практическое значение) / Г. А. Новиков, А. Э. Айрапетьянц, Ю. Б. Пукинский, П. П. Стрелков, Е. К. Тимофеева. - Ленинград : Изд-во ЛГУ, 1970. - 360 с.

88. Воронов, Н. П. Роль роющей деятельности млекопитающих в жизни лесных ценозов : автореф. дис. ... канд. биол. наук / Воронов Н. П. - Казань, 1953. - 18 с.

89. Даль, В. И. Толковый словарь живого великорусского языка / В. И. Даль. - Москва : Русский язык, 1998. Т. $1 .-699 \mathrm{c}$.

90. Сибирский охотник. - 2020. - URL: https://www.hunting.ru/gallery/view/37268/

91. Ситникова, Е. Ф. Поведение выводка барсучат (Meles meles) возле норы / Е. Ф. Ситникова // IV Всероссийская конференция по поведению животных. - Москва : Т-во научных изданий КМК, 2007. C. $410-411$.

92. Рожнов, В. В. Поведенческая экология барсуков. Опыт сбора данных с помощью фотоловушек / В. В. Рожнов, Н. В. Сидорчук. - Москва : Т-во научных изданий КМК, 2016. - 104 с.

93. Кормовые растения сенокосов и пастбищ СССР. - Москва - Ленинград : Изд-во с.-х. лит., 1951. - Т. 2. $948 \mathrm{c}$.

94. Denslow, J. S. Tropical rainforest gaps and tree species diversity / J. S. Denslow // Ann. Rev. Ecol. System. 1987. - Vol. 18. - P. 93-104.

95. Thompson, K. The soil seed banks of North West Europe / K. Thompson, J. Bakker, R. Bekker. - Cambridge, 1996. $-288 \mathrm{p}$.

96. Словарь русского языка. - Москва : Русский язык, 1986. - Т. 2. - 736 с.

97. Сержанин, И. Н. Млекопитающие Белорусской ССР / И. Н. Сержанин. - Минск : АН Белорусской ССР, 1955. $-312 \mathrm{c}$.

98. Гусев, А. А. Функциональная роль диких копытных животных в заповедных биогеоценозах / А. А. Гусев // Роль крупных хищников и копытных в биоценозах заповедников. - Москва : Гл. упр. охотничьего хоз-ва и заповедников, 1986. - С. 94-105.

99. Завьялова, Л. Ф. Биогеоценотическая роль кабана в Дарвинском заповеднике и его значение в соседних сельхозугодьях / Л. Ф. Завьялова // Научные исследования в заповедниках и национальных парках России (федеральный отчет за 1992-1993 годы). - Москва : ВНИИ охраны природы, 1997. - С. 99-100.

\section{References}

1. Vostochnoevropeyskie lesa: istoriya $v$ golotsene $i$ sovremennost' [East European forests: history in the Holocene and modern times]. Execut. ed. O. V. Smirnova. Moscow: Nauka, 2004, bk. 1, 479 p. [In Russian]

2. Vostochnoevropeyskie shirokolistvennye lesa [East Europearn broad-leaved forests]. Ed. by O. V. Smirnova. Moscow: Nauka, 1994, 364 p. [In Russian]

3. Evstigneev O. I. Mekhanizmy podderzhaniya biologicheskogo raznoobraziya lesnykh biogeotsenozov: dis. $d$-ra biol. nauk [Mechanisms of preserving biological diversity of forest biogeocenoses: thesis of doctor of biological sciences. Nizhniy Novgorod, 2010, 513 p. [In Russian] 
4. Evstigneev O. I., Solonina O. V. Byulleten' Moskovskogo obshchestva ispytateley prirody. Otdel biologicheskiy [Bulletin of Moscow society of naturalists: biological series]. 2016, vol. 121, iss. 2, pp. 59-65. [In Russian]

5. Krasnaya kniga Bryanskoy oblasti [Red Book of the Bryansk Region]. Bryansk: RIO BGU, 2016, 432 p. [In Russian]

6. Sitnikova E. F., Mishta A. V. Fauna pozvonochnykh zhivotnykh zapovednika «Bryanskiy les» (ptitsy, mlekopitayushchie) [Fauna of the vertebrates of the nature reserve "Bryansky Les" (birds, mammals)]. Bryansk: Desyatochka, 2008, pp. 50-84. [In Russian]

7. Geptner V. G., Naumov N. P., Yurgenson P. B., Sludskiy A. A., Chirkova A. F., Bannikov A. G. Mlekopitayushchie Sovetskogo Soyuza [Mammals of the Soviet Union]. Moscow: Vysshaya shkola, 1967, vol. 2, 1004 p. [In Russian]

8. Lobachev Yu. S. Byulleten' Moskovskogo obshchestva ispytateley prirody. Otdel biologicheskiy [Bulletin of Moscow society of naturalists: biological series]. 1976, vol. 80, iss. 5, pp. 7-21. [In Russian]

9. Likhachev G. N. Sbornik materialov po rezul'tatam izucheniya mlekopitayushchikh v gosudarstvennykh zapovednikakh [Collection of articles of the results of studying mammals in state nature reserves]. Moscow: Minsel'khoz SSSR, 1956, pp. 72-94. [In Russian]

10. Stroganov S. U. Zveri Sibiri. Khishchnye [Animals of Siberia. The carnivores]. Moscow: AN SSSR, 1962, 458 p. [In Russian]

11. Gorshkov P. K. Prirodnye resursy Volzhsko-Kamskogo kraya, zhivotnyy mir [Natural resources of the VolgaKama region, fauna]. Kazan: Izd-vo Kazanskogo un-ta, 1964, iss. 1, pp. 46-52. [In Russian]

12. Barabash L. A., Shibanov V. V. Biotekhnologiya. Teoreticheskie osnovy i prakticheskie raboty v Sibiri [Theoretical principles and practical work in Siberia]. Novosibirsk: Nauka, 1980, pp. 197-216. [In Russian]

13. Bolysov S. I. Biogennoe rel'efoobrazovanie na sushe. Zonal'nost' [Biogenic relief formation on land. Zoning]. Moscow: Geos, 2007, vol. 2, 466 p. [In Russian]

14. Animalistika Alekseya Subbotina [Animalier art by Aleksei Subbotin]. 2013. Available at: http://www.alekseysubbotin.ru/index.html [In Russian]

15. Rastitel'nost' Evropeyskoy chasti SSSR [Vegetation in the European part of the USSR]. Leningrad: Nauka, 1980, 429 p. [In Russian]

16. Fedotov Yu. P. Izuchenie $i$ okhrana biologicheskogo raznoobraziya Bryanskoy oblasti [Studying and protecting biological diversity of the Bryansk region]. Trubchevsk: Zapo-vednik «Bryanskiy les», 2005, iss. 1, pp. 8-17. [In Russian]

17. Kuznetsov B. A. Ocherk zoogeograficheskogo rayonirovaniya SSSR [Reviews on zoogeographical zoning of the USSR]. Moscow: Izd-vo MGU, 1950, 176 p. [In Russian]

18. Mirkin B. M., Rozenberg G. S., Naumova L. G. Slovar' ponyatiy i terminov sovremennoy fitotsenologii [Dictionary of terms and concepts of modern phitocenology]. Moscow: Nauka, 1989, 223 p. [In Russian]

19. Maevskiy P. F. Flora sredney polosy Evropeyskoy chasti Rossii [Flora of the central part of European Russia]. Moscow: T-vo nauchnykh izdaniy KMK, 2006, 600 p. [In Russian]

20. Khanina L. G., Zaugol'nova L. B., Smirnov V. E., Glukhova E. M. Otsenka i sokhranenie bioraznoobraziya lesnogo pokrova $v$ zapovednikakh Evropeyskoy Rossii [Evaluating and preserving biodiversity of forest cover in nature reserves of European Russia]. Moscow: Nauchnyy mir, 2000, pp. 30-45. [In Russian]

21. Nitsenko A. A. Botanicheskiy zhurnal [Botanical journal]. 1969, vol. 54 (7), pp. 1002-1014. [In Russian]

22. Smirnov V. E., Khanina L. G., Bobrovskiy M. V. Byulleten' Moskovskogo obshchestva ispytateley prirody. Otdel biologicheskiy [Bulletin of Moscow society of naturalists: biological series]. 2006, vol. 111, iss. 2, pp. 36-46. [In Russian]

23. Smirnova O. V., Chistyakova A. A. Zhurnal obshchey biologii [Journal on general biology]. 1980, vol. 41, no. 3, pp. 350-362. [In Russian]

24. Smirnova O. V. Struktura travyanogo pokrova shirokolistvennykh lesov [Structure of grass cover of broad-leaved forests]. Moscow: Nauka, 1987, 208 p. [In Russian]

25. Khitrovo V. N. Zapiski Kievskogo obshchestva estestvoispytateley [Proceedings of Kiev society of naturalists]. Kiev: Tip. Impera-torskogo un-ta Sv. Vladimira, 1910, vol. 10, iss. 3, pp. 251-274. [In Russian]

26. Il'inskiy A. P. Priroda [Nature]. 1945, no. 5, pp. 45-55. [In Russian]

27. Levina R. E. Sposoby rasprostraneniya plodov $i$ semyan [Ways of spreading fruit and seeds]. Moscow: Izd-vo MGU, 1957, 358 p. [In Russian]

28. Levina R. E. Morfologiya i ekologiya plodov [Morphology and ecology of fruit]. Leningrad: Nauka, 1987,160 p. [In Russian]

29. Yurgenson P. B. Barsuk. Pushnye zveri [Badger. Fur-bearing animals]. Moscow: Vneshtorgizdat, 1932,28 p. [In Russian]

30. Evstigneev O. I. Nerusso-Desnyanskoe poles'e: istoriya prirodopol'zovaniya [Nerusso-Desna forest region: history of nature management]. Bryansk: Desyatochka, 2009, 139 p. [In Russian]

31. Ivanter E. V. Trudy gosudarstvennogo zapovednika «Kivach» [Proceedings of "Kivach" nature reserve]. Petrozavodsk: Kareliya, 1973, pp. 164-173. [In Russian]

32. Zharkov I. V., Teplov V. P. Raboty Volzhsko-Kamskoy zonal'noy okhotnich'e-promyslovoy biologicheskoy stantsii. [Proceedings of Volga-Kama regional hunting and fishing biological station]. 1932, iss. 2, pp. 110-124. [In Russian] 
33. Algul'yan S. G. Zoologicheskiy zhurnal [Zoolgical journal]. 1940, vol. 19, no. 3, pp. 499-508. [In Russian]

34. Savvina M. I. Trudy Krymskogo gosudarstvennogo zapovednika [Proceedings of the Crimea State Reserve]. Moscow: Gl. upr. po zapovednikam, zooparkam i zoosadam, 1940, iss. 2, pp. 228-250. [In Russian]

35. Brudin I. D. Priroda [Nature]. 1959, no. 11, p. 118. [In Russian]

36. Ivanova G. I. Materialy po faune $i$ ekologii zhivotnykh [Proceedings on fauna and ecology of animals]. Moscow: MGPI im. V. I. Lenina, 1962, pp. 210-256. [In Russian]

37. Korchmar' N. D. Voprosy ekologii i prakticheskogo znacheniya ptits i mlekopitayushchikh Moldavii [Issues on ecology and practical value of birds and mammals of Moldova]. Kishinev: Shtinitsa, 1962, iss. 1, pp. 56-63. [In Russian]

38. Danilov P. I., Tumanov I. L. Kun'i severo-zapada SSSR [Badgers and weasels of the USSR north and west]. Leningrad: Nauka, 1976, 356 p. [In Russian]

39. Zakirov A. Uzbekskiy biologicheskiy zhurnal [Uzbek biological journal]. 1976, no. 5, pp. 49-50. [In Russian]

40. Smirnov M., Noskov V. Okhota i okhotnich'e khozyaystvo [Hunting and game husbandry]. 1977, no. 2, pp. 12-14. [In Russian]

41. Gorshkov P. K. Prirodnye resursy Volzhsko-Kamskogo kraya, zhivotnyy mir [Natural resources of the VolgaKama region, fauna]. Kazan: Izd-vo Kazansko-go un-ta, 1978, iss. 5, pp. 79-95. [In Russian]

42. Gorshkov P. K. Barsuk v biotsenozakh respubliki Tatarstan [Badger in Tatarstan biocenoses]. Kazan: Tabigat', 1997, 176 p. [In Russian]

43. Ashby K. R., Elliot K. Acta Zool. Fennica. 1983, vol. 174, pp. 205-207.

44. Borodin P. L. Sravnitel'naya ekologiya barsuka, lisitsy, enotovidnoy sobaki i ikh biotsenoticheskoe zna-chenie $v$ Mordovskom zapovednike: dis. kand. biol. nauk [Comparative ecology of badger, fox, raccoon dog and their biocenotic value for Mordovian nature reserve: thesis of the candidate of biological sciences]. Moscow, $1984,271 \mathrm{p}$. [In Russian]

45. Shibanov V. V. Barsuk (Meles meles L.), korsak (Vulpes carsac L.) i lisitsa (Vulpes vulpes L.) BarabinskoKulindinskoy nizmennosti (ekologiya, etologiya, biotsenoticheskoe i prakticheskoe znachenie): avtoref. dis. kand. biol. nauk [Badger (Meles meles L.), corcac fox (Vulpes carsac L.) and fox (Vulpes vulpes L.) of BarabinskKulindinsk lowland: abstract of thesis of the candidate of biological sciences]. Novosibirsk, 1989, 23 p. [In Russian]

46. Goszczyński J., Jędrzejewska B., Jędrzejewski W. Journ. Zool. 2000, vol. 250, pp. 495-505.

47. Minakov I. A. Barsuk (Meles anakuma Temminck, 1844) v lesostepyakh vostochnoy chasti Minusinskoy kot-loviny (areal, morfologiya, ekologiya, resursy): dis. kand. biol. nauk [Badger in forest steppes of eastern part of Minusinsk depression (habitat, morphology, ecology, resourses): theisis of candidate of biological sciences]. Krasnoyarsk, 2004, 155 p. [In Russian]

48. Dikiy I., Dika O. Naukoviy visnik Uzhgorods'kogo universitetu. Ser.: Biologiya [Science bulletin of Uzhgorod University: biological series]. 2005, iss. 17, pp. 42-49.

49. Solov'ev V. A. Biologiya i khozyaystvennoe znachenie barsukov Vyatsko-Kamskogo mezhdurech'ya: dis. kand. biol. nauk [Biology and economic importance of badgers of Vyatka-Kama region: thesis of candidate of biological sciences]. Kirov, 2007, 162 p. [In Russian]

50. Sidorchuk N. V., Rozhnov V. V. Evropeyskiy barsuk v Darvinskom zapovednike. Traditsionnye i novye metody $v$ izuche-nii ekologii i povedeniya nornykh khishchnikov [European badger in Darwin reserve. Traditional and modern methods in studying ecology and behavior of burrowing carnovores]. Moscow: T-vo nauchnykh iz-daniy KMK, 2010, 122 p. [In Russian]

51. Zagaynova O. S., Markov N. I. Ekologiya [Ecology]. 2011, no. 5, pp. 373-383. [In Russian]

52. Neal E. The badger. London: Collins, 1948, 155 p.

53. Levina R. E. Reproduktivnaya biologiya semennykh rasteniy (obzor problemy) [Reproductive biology of seed plants (overview of the problem)]. Moscow: Nauka, 1981, 96 p. [In Russian]

54. Borodina M. N., Borodin L. P., Tereshkin I. S., Shtarev Yu. F. Trudy Mordovskogo gosudarstvennogo zapovednika im. P. G. Smidovicha [Proceedings of Mordovina State Nature Reserve named after P.G. Smidovich]. 1970, iss. 5, pp. 5-60. [In Russian]

55. Polozhentsev P. A. Astanin L. P. Trudy Bashkirskogo sel'skokhozyaystvennogo institute [Proceedings of Bashkir Agricultural Institute]. 1942, vol. 3, pp. 128-138. [In Russian]

56. Obraztsov B. V. Soobshcheniya laboratorii lesovedeniya [Articles of laboratory for forest studies]. 1961, iss. 3, pp. 69-88. [In Russian]

57. Neal E. G., Roper T. J. The environmental impact burrowing animals and animal burrows. 1991, no. 63, pp. 89106.

58. Mlekopitayushchie Kazakhstana. Khishchnye (kun'i, koshki) [Carnovores (badgers and weasels, cats]. Alma-Ata: Nauka Kazakhskoy SSR, 1982, vol. 3, part 2, 263 p. [In Russian]

59. Korotkov V. N. Demutatsionnye protsessy v ostrovnykh lesnykh massivakh (na primere GIZL «Gorki Leninskie» $i$ Kanevskogo zapovednika): avtoref. dis. kand. biol. nauk [Demutational processes in insular forest areas (on the example of "Gorki Leninskie" and Kanevsky reserve]. Moscow, 1992, 16 p. [In Russian]

60. Evstigneev O. I., Murashev I. A., Korotkov V. N. Lesovedenie [Forest studies]. 2017, no. 1, pp. 45-52. [In Russian] 
61. Evstigneev O. I., Voevodin P. V., Korotkov V. N., Murashev I. A. Uspekhi sovremennoy biologii [Achievements of modern biology]. 2013, vol. 133, no. 4, pp. 392-400. [In Russian]

62. Evstigneev O. I., Korotkov V. N., Murashev I. A., Voevodin P. V. Russian Journal of Ecosystem Ecology. 2017, vol. 2, no. 1, pp. 1-16. DOI 10.21685/2500-0578-2017-1-2.

63. Danilov P. I., Tumanov I. L. Sbornik nauchno-tekhnicheskoy informatsii (okhota, pushnina i dich') [Collection of research and technical information (hunting, pelts, game meat]. Kirov: VNIIOZ, 1971, iss. 34, pp. 25-31. [In Russian]

64. Kowalczyk R., Zalewski A., Jędrzejewska B. Wildlife biology. 2006, vol. 12, no. 4, pp. 385-391.

65. Harlow H. J. J. Mamm. 1981, vol. 62, no. 1, pp. 173-177.

66. Pazhetnov V. S. Buryy medved' [Brown bear]. Moscow: Agropromizdat, 1990, 215 p. [In Russian]

67. Kruuk H. H., Parish T. Journal. of Animal Ecology. 1987, vol. 56, no. 1, pp. 351-364.

68. Sabdinova D. K. Osobennosti ekologii barsuka (Meles meles) v Ishimskoy lesostepi Kazakhstana: dis. kand. biol. nauk [Features of badgers' ecology in Ishimsk forest steppe of Kazakhstan: thesis of candidate of biological sciences]. Omsk, 2005, 117 p. [In Russian]

69. Evstigneev O. I., Murashev I. A., Romanov M. S. Russian Journal of Ecosystem Ecology. 2018, vol. 3, no. 1, pp. 1-18. DOI 10.21685/2500-0578-2018-1-1.

70. Kazakova M. V. Flora Ryazanskoy oblasti [Flora of the Ryazan region]. Ryazan: Russkoe slovo, 2004,388 p. [In Russian]

71. Formozov A. N. Priroda goroda Moskvy i Podmoskov'ya [Nature of Moscow City and Moscow Region]. Moscow - Leningrad: AN SSSR, 1947, pp. 287-370. [In Russian]

72. Dinesman L. G. Botanicheskiy zhurnal [Botanical journal]. 1968, vol. 53 (2), pp. 214-222. [In Russian]

73. Lavrovskiy V. V. Trudy Okskogo gosudarstvennogo prirodnogo biosfernogo zapovednika [Proceedings of Oksk State Nature Biosphere Reserve]. Ryazan, 2005, iss. 24, pp. 173-182. [In Russian]

74. Sitnikova E. F. Dinamika populyatsiy okhotnich'ikh zhivotnykh severnoy Evropy: Mezhdunarodnyy simpozium [Dynamics of population of hunting animals in Northern Europe: International symposium]. Petrozavodsk, 2010, pp. 174-175. [In Russian]

75. Roper T. J., Tait A. I., Fee D., Christian S. F. J. Zool. 1991, vol. 225, no. 1, pp. 115-124.

76. Neal E. G. Animal of Britain. 1962, no. 1, 25 p.

77. Evstigneev O. I. Vostochnoevropeyskie lesa: istoriya v golotsene i sovremennost' [East European forests: history in the Holocene and modern times]. Moscow: Nauka, 2004, bk. 2, pp. 266-278. [In Russian]

78. Borodin P. L. Ekologo-faunisticheskie issledovaniya v Nechernozemnoy zone RSFSR: mezhvuz. sb. nauch. tr. [Research into ecology and fauna in nonchernozem belt of the RSFSR: interuniversity collection of articles]. Saransk: Mordovskiy gos. un-t, 1983, pp. 5-15. [In Russian]

79. Smirnova O. V. Vostochnoevropeyskie lesa: istoriya v golotsene i sovremennost' ${ }^{\prime}$ East European forests: history in the Holocene and modern times]. Moscow: Nauka, 2004, bk. 1, pp. 25-43. [In Russian]

80. Voronov A. G. Geobotanika [Geobotany]. Moscow: Vyssh. shk., 1973, 384 p. [In Russian]

81. Gilyarov V. G. Doklady AN SSSR [Reports of the Academy of Sciences of the USSR]. 1951, vol. 79, no. 4, pp. 669-671. [In Russian]

82. Bykov B. A. Geobotanika [Geobotany]. Alma-Ata: AN Kazakhskoy SSR, 1953, 458 p. [In Russian]

83. Evstigneev O. I., Korotkov V. N., Belyakov K. V., Braslavskaya T. Yu., Romanovskiy A. M., Rubashko G. E., Sarycheva E. P., Fedotov Yu. P. Biogeotsenoticheskiy pokrov Nerusso-Desnyanskogo Poles'ya: mekhanizmy podderzhaniya biologicheskogo raznoobraziya [Biogeocenotic cover of Nerusso-Desna forest region: mechanisms of preserving biological diversity]. Bryansk: Zapovednik «Bryanskiy les», 1999, 176 p. [In Russian]

84. Borodin P. L. Fauna i ekologiya zhivotnykh [Fauna and ecology of animals]. Moscow: MGPI im. V. I. Lenina, 1976, pp. 145-156. [In Russian]

85. Dvornikov M. G., Dvornikova N. P., Korobeynikova V. P. Ekologiya [Ecology]. 1994, vol. 5-6, pp. 108-109. [In Russian]

86. Kerzina M. N. Rol' zhivotnykh v zhizni lesa [Role of animals in the life of a forest]. Moscow: Izd-vo MGU, 1956, pp. 217-304. [In Russian]

87. Novikov G. A., Ayrapet'yants A. E., Pukinskiy Yu. B., Strelkov P. P., Timofeeva E. K. Zveri Leningradskoy oblasti (fauna, ekologiya i prakticheskoe znachenie) [Animals of the Leningrad region (Fauna, ecology and practical importance)]. Leningrad: Izd-vo LGU, 1970, 360 p. [In Russian]

88. Voronov N. P. Rol' royushchey deyatel'nosti mlekopitayushchikh v zhizni lesnykh tsenozov: avtoref. dis. kand. biol. nauk [The role of rooting of mammals in the life of forest cenoses: abstract of thesis of candidate of biological sciences]. Kazan, 1953, 18 p. [In Russian]

89. Dal', V. I. Tolkovyy slovar' zhivogo velikorusskogo yazyka [Explanatory Dictionary of the Live Great Russian Language]. Moscow: Russkiy yazyk, 1998, vol. 1, 699 p. [In Russian]

90. Sibirskiy okhotnik [Siberian hunter]. 2020. Available at: https://www.hunting.ru/gallery/view/37268/ [In Russian]

91. Sitnikova E. F. IV Vserossiyskaya konferentsiya po povedeniyu zhivotnykh [IV All-Russian conference on animal behaviour]. Moscow: T-vo nauchnykh izdaniy KMK, 2007, pp. 410-411. [In Russian]

92. Rozhnov V. V., Sidorchuk N. V. Povedencheskaya ekologiya barsukov. Opyt sbora dannykh s pomoshch'yu fotolovushek [Behavioural ecology of badgers. Experience of collecting data with the help of trap cameras]. Moscow: T-vo nauchnykh izdaniy KMK, 2016, 104 p. [In Russian] 
93. Kormovye rasteniya senokosov $i$ pastbishch SSSR [Forages of hayfields and pastures in the USSR]. Moscow Leningrad: Izd-vo s.-kh. lit., 1951, vol. 2, 948 p. [In Russian]

94. Denslow J. S. Ann. Rev. Ecol. System. 1987, vol. 18, pp. 93-104.

95. Thompson K., Bakker J., Bekker R. The soil seed banks of North West Europe. Cambridge, 1996, 288 p.

96. Slovar' russkogo yazyka [Dictionary of the Russian language]. Moscow: Russkiy yazyk, 1986, vol. 2, 736 p. [In Russian]

97. Serzhanin I. N. Mlekopitayushchie Belorusskoy SSR [Mammals of the BSSR]. Minsk: AN Belorusskoy SSR, 1955, 312 p. [In Russian]

98. Gusev A. A. Rol' krupnykh khishchnikov i kopytnykh v biotsenozakh zapovednikov [Role of large carnivores and ungulates in biocenoses of nature reserves]. Moscow: Gl. upr. okhotnich'ego khoz-va i zapovednikov, 1986, pp. 94-105. [In Russian]

99. Zav'yalova L. F. Nauchnye issledovaniya v zapovednikakh i natsional'nykh parkakh Rossii (federal'nyy otchet za 1992-1993 gody) [Research in nature reserves and national parks of Russia (federal report on 1992-1993)]. Moscow: VNII okhrany prirody, 1997, pp. 99-100. [In Russian] 